RADOVI

UDK 78.034.7(497.523Varaždin)“1983/2019“

Zavoda za znanstveni rad

Izvorni znanstveni članak

HAZU Varaždin

Original Scientific Paper

EDUARD VARGOVIĆ

Primljeno: 10. 01. 2020.

Varaždin

Prihvaćeno: 10. 06. 2020.

eduard.vargovic@vz.t-com.hr

DOI: 10.21857/m16wjceo89

\title{
VARAŽDINSKE BAROKNE VEČERI - U SUSRET 50 FESTIVALSKIH GODIŠTA - ZNANSTVENI SKUPOVI I DJELOVANJE ZAVODA HAZU VARAŽDIN U PROUČAVANJU GLAZBENE BAŠTINE OD 1983. DO 2019. GODINE
}

Varaždinske barokne večeri ulaze u svoje 50-godišnje uspješno djelovanje (1971. -2020.). Rad tematizira, kao što je zapisano u naslovu, rezultate znanstvenih skupova, ali i djelovanje Zavoda za znanstveni rad Hrvatske akademije znanosti i umjetnosti u Varaždinu na proučavanju glazbene baštine. Održavanje i realizaciju znanstvenih skupova kronološki dijelimo na dva (glavna) razdoblja:

1. Od 1978. do 1983. godine, odnosno do osnivanja Zavoda za znanstveni rad, tada JAZU a danas HAZU, u Varaždinu. Održano je ukupno 6 skupova. 2. Od 1983. do 2019. godine u kojem je održano 19 skupova. Na 25 znanstvenih skupova sudjelovao je ukupno 141 predavač s 220 tema. Najviše sudjelovanja imali su: 1. Dr. sc. Ennio Stipčević, član suradnika HAZU - 11; 2. Akad. Lovro Županović - 10; 3. Dr. sc. Zdenka Weber - 7; 4. Akad. Stanislav Tuksar - 6. Kad je riječ o tiskanju radova izlaganih na skupovima tu je situacija posve drugačija. Od 141 predavača, radove je poslalo 100 autora. To nas vodi do sljedećih zaključaka: 1. Prava je šteta da dobar dio radova, referiranih na skupovima, nije objavljen. Ali to nije nedostatak samo u ovom (našem) slučaju. 2. Treba reći da bogatstvo sadržaja koje smo u tekstu prezentirali, svakako su dokaz uspješnosti Varaždinskih baroknih večeri i suradnje Festivala s uglednim institucijama - MIC/HAZU, kao i afirmiranim, ali i mladim, istraživačima, upisujući se trajno u glazbenu povijest Varaždina. 
EDUARD VARGOVIĆ: Varaždinske barokne večeri - u susret 50 festivalskih godišta...

Ključne riječi: znanstveni skupovi; Hrvatska akademija znanosti i umjetnosti; Varaždinske barokne večeri; Varaždin.

\section{NA TRAGU PRIZNATE TRADICIJE}

Akademik Ladislav Šaban"1 objavio je 1978. studiju: "Glazbene mogućnosti Varaždina u 18. st. i prvoj polovici 19. stoljeća"2 iz koje izdvajamo nekoliko razmišljanja o glazbenom životu Varaždina u 18. i prvoj polovici 19. stoljeća. Najprije jedna misao koja pokazuje mjesto Varaždina u glazbenom života kontinentalne Hrvatske: "Grad koji uoči požara 1776. na zenitu broji samo 3580 stanovnika, razvija glazbeni potencijal kakav nije mogao razviti ni jedan od gradova kontinentalne Hrvatske". ${ }^{3}$

Kakav uistinu glazbeni život Varaždina Šaban zapisuje? "U to vrijeme (sredina 18. st.) kao da u Varaždinu sve vrije od glazbene djelatnosti. Samostani isusovaca i uršulinki natječu se tko će se iskazati biranijom glazbom. Njihovi crkveni obredi i školske priredbe prati svirka glazbenih sastava često nalik koncertnim priredbama danas (...) Napokon palače istaknutih velikaša postaju središta osobite njege glazbe visoke umjetničke vrijednosti, koja drži korak s najnovijim dostignućima u metropoli, carskom Beču". ${ }^{4}$

U kontekstu rečenog potvrdno zvuče i riječi Vladimira Kranjčevića koji piše: „Postojanje Varaždinskih baroknih večeri utemeljeno je u skladu sa sredinom u kojoj je ovaj jedinstveni festival niknuo, a to je povijesni, hrvatski i kraljevski grad Varaždin. No, Varaždinske barokne večeri na svoj način odslikavaju i cjelokupno bogatstvo umjetničke baštine ovog osam stoljeća živoga Grada i sjeverozapadne Hrvatske". ${ }^{5}$

Uz ovu posve točnu konstataciju maestra V. Kranjčevića čitatelja upućujemo na jednu zanimljivost na koju nas podsjeća Zdenka Weber kad piše: "Tako

1 Ladislav Šaban (1918. - 1985.).

2 Ladislav ŠABAN, "Glazbene mogućnosti Varaždina u 18. st. i prvoj polovici 19. stoljeća", RAD, JAZU broj 377, 1978.

3 Šaban, isto, str. 189.

4 Šaban, isto, str. 188. Želimo upozoriti na njegov rad Glazbena kultura u varaždinskoj okolici u 17. i 18. stoljeću., Glazbena baština, MIC i Varaždinske barokne večeri, knjiga 3, Zagreb-Varaždin, 1980. str. 2350. Teškoće u istraživanju glazbene kulture - baštine Šaban naglašava već u prvim rečenicama: “Nije lako pisati o glazbenoj kulturi jedne regije o kojoj se iz starijih dana sačuvalo iznimno malo izvorne glazbene građe", str. 23.

5 Vladimir KRANJČEVIĆ, "Bogatstvo barokne glazbene baštine". U Varaždinske barokne večeri - 25 festivalskih godina, Varaždin 1995., urednici: Ernest Fišer i Jagoda Martinčević, str. 7. 
je primjerice, 10. siječnja 1961. godine u Varaždinu održana „Večer muzičkog baroka", uz sudjelovanje komornog orkestra i flautiste Emerika Gregura, a dirigirao je Davorin Hauptfeld. Za Krešimira Filića je to povod komentaru kako je Davorin Hauptfeld „dokazao, što se može postići s manjim orkestrom u malenom gradu“. 6

\section{ZNANSTVENI SKUPOVI}

U organizaciji manifestacije Varaždinske barokne večeri znanstveni skupovi pripadaju popratnim programima Festivala. Bogatstvo programa u vremenskom razdoblju 1971. - 2019. godine pregledno i uvjerljivo prikazujemo u slijedećoj tablici:

Tablica 1: Popratni programi Varaždinskih baroknih večeri 1971. - 2019.

\begin{tabular}{|l|l|l|l|}
\hline Redni broj & Naziv manifestacije & Ukupan broj & Napomena \\
\hline 1. & Izložbe & \multicolumn{1}{|c|}{189} & \\
\hline 2. & Znanstveni skupovi & $\begin{array}{l}25 \text { (uključen i } \\
\text { svečani koncert uz } \\
\text { obljetnicu HAZU } \\
2011 .)\end{array}$ & $\begin{array}{l}\text { Objašnjenje u tekstu } \\
\text { o znanstvenim } \\
\text { skupovima }\end{array}$ \\
\hline 3. & $\begin{array}{l}\text { Predavanja, razgovori, } \\
\text { glazbeni programi, } \\
\text { seminari, radionice, } \\
\text { multimedijski programi }\end{array}$ & 54 & \\
\hline 4. & Kazališne predstave & 27 & $\begin{array}{l}\text { Predstavljanja i } \\
\text { promocije }\end{array}$ \\
\hline 5. & $\begin{array}{l}\text { Književne večeri, } \\
\text { obljetnice }\end{array}$ & 61 & $\begin{array}{l}\text { Gastronomija, } \\
\text { degustacije, }\end{array}$ \\
\hline 6. & \begin{tabular}{l} 
Filmovi \\
\hline 7.
\end{tabular} & 95 & \\
\hline
\end{tabular}

6 Zdenka WEBER, "Varaždinski festival - plod sjajne glazbene tradicije baroknoga grada". U Varaždinske barokne večeri - 25 festivalskih godina, Varaždin, 1995., str. 20. 
EDUARD VARGOVIĆ: Varaždinske barokne večeri - u susret 50 festivalskih godišta...

\begin{tabular}{|l|l|l|l|}
\hline 9. & Vatromet & 24 & $\begin{array}{l}\text { Prvi : 1988. } \\
\text { Od 1996. - 2013. i } \\
\text { 2015. } \\
\text { Prvi vatromet } \\
\text { na glazbu G. F. } \\
\text { Händela: Muzika za } \\
\text { kraljevski vatromet } \\
\text { bio je 28. rujna } \\
\text { 1990. na bedemima } \\
\text { Starog grada. }\end{array}$ \\
\hline 10. & Mise & $\begin{array}{l}\text { 3 (mise izvan } \\
\text { završnog programa } \\
\text { na kraju VBV) }\end{array}$ & \\
\hline 11. & $\begin{array}{l}\text { Otkrivanje spomen } \\
\text { ploča }\end{array}$ & 2 & \\
\hline 12. & Ostale manifestacije & 17 & \\
\hline 13. & $\begin{array}{l}\text { Ukupno od 1970. - } \\
\text { 2019. }\end{array}$ & 442 & \\
\hline
\end{tabular}

Popratni sadržaji u cjelini, ali i pojedinačno, nisu predmet našeg interesa. Ipak, već i na prvi pogled može se vidjeti bogatstvo najrazličitijih programâ koji su kroz 49. godišta pratili Festival u vrijeme njegova trajanja. ${ }^{7}$

\section{Znanstveni skupovi - kronologija}

Organizaciju i realizaciju znanstvenih skupova kronološki dijelimo na dva (glavna) razdoblja:

1. Prvi je period od 1978. do 1983. tj. do osnivanja Zavoda za znanstveni rad, tada JAZU a danas HAZU, u Varaždinu. ${ }^{8}$ Održano je ukupno 6 skupova.

2. Drugo je razdoblje od 1983. do 2019., u kojem je održano 19 skupova.

\section{Znanstveni skupovi 1978. - 1983. godine}

Prvi skup održan je 1978. godine. Iz sadržaja Pozivnice saznajemo da je skup održan u Gradskoj vijećnici 22. i 23. rujna s početkom u 10 sati. Od 1978. do 1983. održano je 6 skupova. Godine 1981. Varaždin je obilježio 800 godina

7 Više o popratnim programima vidjeti u radu Eduard VARGOVIĆ, Vladimir HUZJAN: "Vrijednost i značaj popratnih programa 45 festivalskih godina Varaždinskih baroknih večeri 1971. - 2015.", Radovi Zavoda za znanstveni rad Varaždin, 27, Hrvatska akademija znanosti i umjetnosti, Zavod za znanstveni rad u Varaždinu, Zagreb-Varaždin, 2016., 169-235.

8 Zavod je osnovan 24. lipnja 1983. potpisivanjem tadašnjeg Samoupravnog sporazuma između Akademije i Skupštine općine Varaždin (op. a.). 
prvog spomena. Upravo u vrijeme Festivala održan je trodnevni međunarodni skup na kojem su prezentirane i teme vezane za glazbu. ${ }^{9}$ Organizaciju skupova potpisuje MIC - Muzički informativni centar Zagreb i Varaždinske barokne večeri. U toj organizaciji i moderiranju skupova naročite zasluge pripadaju muzikologinji Eriki Krpan koja je i danas aktivna. Doista, kada se pregledaju sadržaji i autori koji su sudjelovali svojim radovima, Erika Krpan svojim je marljivim i upornim organizacijskim radom, ali i kao muzikologinja, bitno pridonijela novim spoznajama koje su prezentirane na znanstvenim susretima, povezujući, vrlo uspješno, znanstvenike iz cijele tadašnje Jugoslavije. Na tim susretima, od 1978. do 1983., sudjelovali su autori iz: Zagreba, Beograda, Skoplja, Sarajeva, Podgorice, Kotora i jedan iz Beča. Popis svih autora do 2019. godine izgleda ovako: Ljubljana, Beograd, Skoplje, Kotor, Sarajevo, Podgorica, Novi Sad, Beč, Zagreb, Varaždin, te iz država poput Češke, Njemačke, Engleske, Novog Zelanda i SAD-a, te Slovenije i Švedske.

O važnosti znanstvenih skupova, odnosno Savjetovanja, L. Županović piše: "Bez obzira na to što se ponekad prekoračilo (barokni) vremenski okvir, Savjetovanja su izvršila pozitivnu ulogu i ispunila očekivanja. Zbog toga bi bila šteta ne nastaviti ih, makar i sustavom bie/trienala i, dakako, s tendecijom traženja mogućih tematskih veza $s$ inozemnom glazbenom situacijom odgovarajućeg razdoblja“. ${ }^{10}$

To potvrđuje i Bosiljka Perić Kempf: “Dosadašnji znanstveni skupovi (do 1995. - E. V.) na Varaždinskim baroknim večerima jasno su ukazali na neophodnost takve vrste festivala komplementarnih sadržaja, kao važnog elementa potpunijim spoznajama o glazbi baroka, koja ostaje jedinom i vječnom festivalskom temom. Jer, koliko muzikološka istraživanja potiču glazbenu praksu, toliko i glazbena praksa utječe na daljnje znanstveno proučavanje. U tom smislu trebalo bi još više potaknuti suradnju muzikologa i izvođača, jer se - kao što inozemni trendovi dokazuju - jedino na toj osnovi međusobnog izmjenjivanja znanstvenih i umjetničkih iskustava može izgraditi jasna slika prošle epohe, njenih stvaralačkih principa i dosega". ${ }^{11}$

9 U Katalogu Varaždinskih baroknih večeri, predsjednik Skupštine općine Varaždin Ćiril Grabrovec u uvodnoj riječi između ostalog piše: „Još za vrijeme trajanje Varaždinskih baroknih večeri otpočet će i znanstveni skup vezan uz 800. godišnjicu Varaždina (...)". Katalog VBV, 1981.

10 Lovro ŽUPANOVIĆ, "Dosadašnji prinos Varaždinskih baroknih večeri istraživanjima hrvatske glazbene bašćine i izvođenja djela iz razdoblja glazbenog baroka". Varaždinske barokne večeri - 25 festivalskih godina, Varaždin 1995., str. 39/40.

11 Bosiljka PERIĆ KEMPF, "Muzikološki skupovi na Varaždinskim baroknim večerima”. Varaždinske barokne večeri - 25 festivalskih godina, Varaždin 1995., str. 42. 
Pišući svoj kronološki pregled o Varaždinskim baroknim večerima Jagoda Martinčević znakovito piše o simpoziju koji je održan u predjubilarnoj godini, naime 1994. (24 godišta Festivala), a na tragu već rečenog o važnosti i znanstvenih skupova, kao drugih važnih čimbenika u razvitku Festivala: " Simpozij o orguljama A. Römera, glasovitog graditelja kojega se tragovi nalaze i u nas, a u sklopu kojeg su sudjelovali naši i inozemni stručnjaci, podsjetio nas je na još jedan prinos Varaždinskih baroknih večeri, koji će osim glazbenih imati i dalekosežne kulturološke posljedice. Tijekom trajanja festivala, inicijativom i zalaganjem organizatora, u barokni su grad stigla dva koncertna „Bösendorfer" glasovira i čembalo "Neupert" za koncertne potrebe, obnovljen je pozitiv, a kao najvažnije - u crkvu Kaptola čazmansko-varaždinskoga (Isusovačku crkvu) iznimnim marom vlč. Alojzija Domislović, lektora Kaptola čazmansko-varaždinskoga, ugrađene su nove orgulje proizvodnje Aug. Laukhuffa iz Weinkersheima, kojih je ugradbu vodio vrstan stručnjak i graditelj Wolfgang J. Braun. Uz obnovu Römerovih orgulja u župnoj crkvi Sv. Martina u Varaždinskim Toplicama, ovi su prinosi koncertantnom instrumentariju varaždinskog okružja od neprocjenjive vrijednosti. Oni su dokaz skrbi varaždinske sredine o budućnosti koja će pamtiti (zahvaljujući i brojnim trajnim zapisima suvremene tehnike) umjetnička postignuća svog festivala, ali će i sama moći sudjelovati u daljnjem trajanju baroknih glazbenih svečanosti. ${ }^{\prime 12}$

Tema skupova u prvom periodu uglavnom je formulirana na prvom susretu: „Glazbena baština naroda i narodnosti Jugoslavije u razdoblju od 16. do 19. stoljeća, te dosadašnji rezultati njezina oživljavanja i uklapanja u našu glazbenu praksu“. Ova tema je zastupljena i na skupu 1988. godine. Naravno, konkretne teme i sadržaji rezultati su posebnih istraživanja autora koji su referirali na znanstvenim skupovima.

12 Jagoda MARTINČEVIĆ, "Dvadeset pet godišta Varaždinskih baroknih večeri", Varaždinske barokne večeri - 25 festivalskih godina, Varaždin 1995. str. 34. 


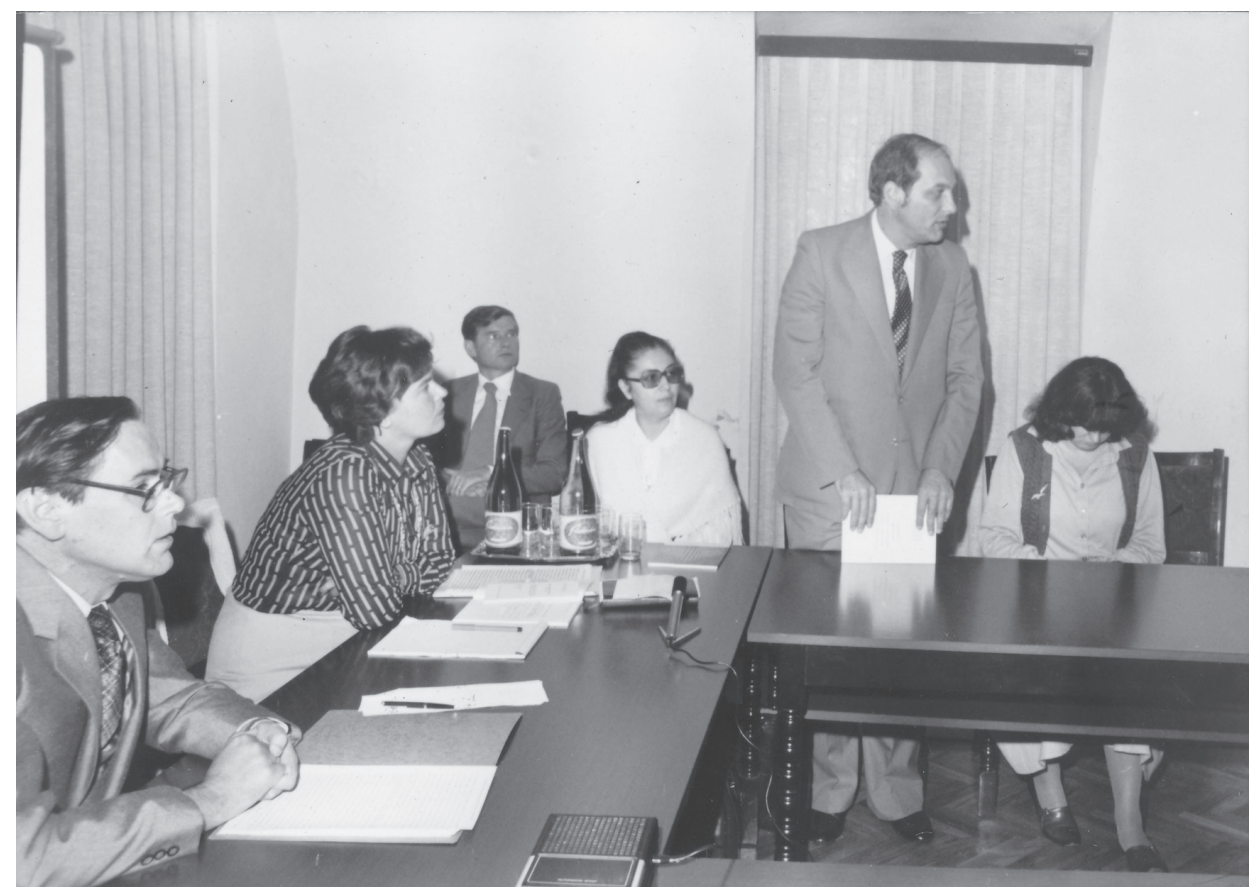

Slika 1. Znanstveni skup 1979. godine ${ }^{13}$

\section{Znanstveni skupovi nakon 1983. godine}

Od 1983., dakle od osnivanja Zavoda, znanstveni skupovi održani su: 1986. 1988. - 1990. - 1991.- 1992. - 1994.- 1995.- 1996.- 1998.-1999.- 2000.-2002.-2010.2011.-2013.- 2014.-2015.-2017. i 2019. To je ukupno 19 skupova. U djelovanju Zavoda, u organizaciji i realizaciji znanstvenih skupova u vrijeme Festivala nemjerljivu ulogu imali su njegov prvi voditelj akad. Andre Mohorovičić, ${ }^{14}$ kao i prvi upravitelj prof. dr. sc. Franjo Ruža. ${ }^{15} \mathrm{Na}$ njihovim zaslugama nastavili su svoj rad i ostali voditelji: akad. Miroslav Šicel ${ }^{16}$ i sadašnji voditelj akad. Stjepan Damjanović, ${ }^{17}$ kao i upravitelji: mr. sc. Ivan Grabar, ${ }^{18} \mathrm{mr}$. sc. Eduard Vargović ${ }^{19} \mathrm{i}$ dr.

\footnotetext{
13 Fotografija: Arhiv Zavoda HAZU Varaždin. Oznaka: HR-A-HAZU-VŽ-1.

14 Akad. Andre Mohorovičić (1913.-2002.). Voditelj Zavoda od 1983. do 2002. godine.

15 Prof. dr. sc. Franjo Ruža (1931.-2017.). Upravitelj Zavoda od 1983. do 1993. godine.

16 Akad. Miroslav Šicel (1926.-2011.). Voditelj Zavoda od 2003. do 2011. godine.

17 Akad. Stjepan Damjanović je voditelj Zavoda od 2012. godine.

18 Mr. sc. Ivan Grabar (1937.-2011.). Bio je upravitelj Zavoda u tijeku 1994. do izbora novog (upravitelja).

19 Mr. sc. Eduard Vargović bio je upravitelj Zavoda od 1994. do kraja 2013.godine.
} 
sc. Vladimir Huzjan. ${ }^{20}$ Prema dokumentaciji ${ }^{21}$ skupovi nisu održani 1984., 1985., 1986,. 1987. i 1989. U godinama 1985. i 1987. održana su pijanistička natjecanja Bach - Händel - Scarlatti.

Tematski na skupovima su definirani slijedeći sadržaji:

1. 1988. Glazbena baština naroda i narodnosti Jugoslavije u razdoblju od 16. do 19. stoljeća te dosadašnji rezultati njezina oživljavanja i uklapanja u našu glazbenu baštinu.

2. 1991. Proučavanje glazbenog baroka u Južnih Slavena. Glazbena baština baroka.

3. 1992. Glazbena baština baroka.

4. 1994. O orguljama Antoniusa Roemera - Turistička zajednica Varaždinske Toplice.

5. 1995. 25. godina Varaždinskih baroknih večeri.

6. 1999. Barok u Varaždinu - jučer, danas, sutra.

7. 2010. Barokna glazba - jučer, danas, sutra, u povodu 40. godina Varaždinskih baroknih večeri 2010.

8. 2015. Varaždinske barokne večeri, 45. festivalskih godišta 1971. - 2015.

9. 2019. Uloga Varaždinskih baroknih večeri u istraživanju, očuvanju i promociji hrvatske baštine baroka u 49 festivalskih godišta.

Pojedini skupovi i događanja posvećeni su: Ivanu Lukačiću (1998.), Vinku Jeliću (1996.), Antoniusu Roemeru - i njegovim orguljama (1994.), Ivanu Padovcu (2000.), Ivanu Krstitelju Vaňhalu (2013.), Jurici Muraiu (2014.). Dva znanstvena skupa nisu posvećena glazbi: 1. 2002. - Promišljanje umjetnosti - u organizaciji: „Udruga za promicanje znanosti“ Zagreb. Simpozij filozofa i teoretičara umjetnosti. 2. 2017. - Obrazovanje za 21. stoljeće u organizaciji Rotary Business Foruma; na FOI Varaždin. Ovom popisu pridodajemo i godinu 2011. kada je održan koncert na Varaždinskim baroknim večerima, koji je bio posvećen 150. obljetnici Hrvatske akademije znanosti i umjetnosti (1861. - 2011.). Riječ je o Carlo Antonio Nagli autoru djela: Messa con instrumenti a 4 concertata (početak 18. st.). ${ }^{22}$

20 Dr. sc. Vladimir Huzjan je upravitelj Zavoda od 2014. godine.

21 Dokumentacija u Zavodu HAZU u Varaždinu.

22 Ennio STIPČEVIĆ, “Carlo Antonio Nagli (c. 1680. - 1756.) i njegova Messa con instrumenti a 4 concertata", Radovi Zavoda za znanstveni rad Varaždin, Hrvatska akademija znanosti i umjetnosti, Zavod za znanstveni rad u Varaždinu, 24, Zagreb-Varaždin, 2013., 195-200. 
Kada se uz nabrojene činjenice prikažu konkretni podaci o autorima priložene tablice pokazuju veličinu i važnost znanstvenih skupova organiziranih u vrijeme Festivala.

Pogledajmo najprije tablicu sudionika skupova:

Tablica 2. Popis sudionika znanstvenih skupova (kronološkim redom) ${ }^{23}$

\begin{tabular}{|l|l|l|l|}
\hline Radni broj & Prezime ime & Godina & Napomena \\
\hline 1. & Danica Petrović - Beograd & 1978. & \\
\hline 2. & Franjo Bilić & 1978. & \\
\hline 3. & Lovro Županović & 1978. & \\
\hline 4. & Gorana Doliner & 1978. & \\
\hline 5. & Stanislav Tuksar & 1978. & \\
\hline 6. & Erika Krpan & 1978. & Voditeljica skupa ${ }^{24}$ \\
\hline 7. & Jože Sivec - Ljubljana & 1979. & \\
\hline 8. & Miloš Milošević - Kotor & 1979. & \\
\hline 9. & Jelica Todorčevska - Skopje & 1979. & \\
\hline 10. & Srećko Lipovčan & 1979. & \\
\hline 11. & Ladislav Šaban & 1979. & \\
\hline 12. & Lovro Županović & 1979. & \\
\hline 13. & Erika Krpan & 1979. & Voditeljica skupa \\
\hline 14. & Dimitrije Stefanović - Beograd & 1980. & \\
\hline 15. & Dragoslav Ortakov - Skopje & 1980. & \\
\hline 16. & Stanislav Tuksar & 1980. & \\
\hline 17. & Koraljka Kos & 1980. & \\
\hline 18. & Vjera Katalinić-Lukšić & 1980. & \\
\hline 19. & Manja Radulović Vulić - Podgorica & 1980. & \\
\hline 20. & Erika Krpan & 1980. & Voditeljica skupa \\
\hline 21. & Andrija Tomašek & 1981. & ZS²5 800 godina Varaždina \\
\hline 22. & Stanislav Tuksar & 1981. & ZS 800 godina Varaždina \\
\hline & & & \\
\hline
\end{tabular}

23 Tablice 2 i 3, u ovom tekstu ažurirane s novim podacima, prvi puta su objavljene u radu: Eduard VARGOVIĆ, Vladimir HUZJAN: "Vrijednosti i značaj popratnih programa 45 festivalskih godišta Varaždinskih baroknih večeri (1971.-2015.)". Radovi Zavoda za znanstveni rad Varaždin, 27, Hrvatska akademija znanosti i umjetnosti, Zavod za znanstveni rad u Varaždinu, Zagreb-Varaždin, 2016. str. 169-234.

24 Moderatori i voditelji skupova svojim su djelovanjem, znanjem i umijećem vođenja, također zaslužni su za njihov uspješan rad.

25 ZS - znanstveni skup (op. a.). 
EDUARD VARGOVIĆ: Varaždinske barokne večeri - u susret 50 festivalskih godišta...

\begin{tabular}{|c|c|c|c|}
\hline 23. & Zdenka Weber & 1981. & ZS 800 godina Varaždin \\
\hline 24. & Ladislav Šaban & 1981. & ZS 800 godina Varaždin \\
\hline 25. & Danica Petrović - Beograd & 1982. & \\
\hline 26. & Gjura Jakšić - Beograd & 1982. & \\
\hline 27. & Miloš Milošević - Beograd & 1982. & \\
\hline 28. & Andrija Tomašek & 1982. & \\
\hline 29. & Lovro Županović & 1982. & \\
\hline 30. & Andre Lengyel (koreferent) & 1982. & \\
\hline 31. & Ennio Stipčević (koreferent) & 1982. & \\
\hline 32. & Erika Krpan & 1982. & Voditeljica skupa \\
\hline 33. & Zija Kučukalić - Sarajevo & 1983. & \\
\hline 34. & Danilo Pokorn & 1983. & \\
\hline 35. & Herbert Seifert - Beč & 1983. & \\
\hline 36. & Hranislav Đurić (Novi Sad) & 1983. & \\
\hline 37. & Zdravko Blažeković & 1983. & \\
\hline 38. & Lovro Županović & 1983. & \\
\hline 39. & Ružica Bonifačić & 1983. & \\
\hline 40. & Enisa Hadrović & 1983. & \\
\hline 41. & Marina Jaman & 1983. & \\
\hline 42. & Tatjana Kovačić & 1983. & \\
\hline 43. & Tatjana Lještak & 1983. & \\
\hline 44. & Maja Oršić & 1983. & \\
\hline 45. & Mirjana Šimundža & 1983. & \\
\hline 46. & Sanja Vukasović & 1983. & \\
\hline 47. & Ennio Stipčević & 1983. & \\
\hline 48. & Ivan Bošković & 1983. & \\
\hline 49. & Lovro Županović & 1986. & Uvodna i završna riječ \\
\hline 50. & Rudolf Flotzinger - Beč & 1986. & \\
\hline 51. & Hellmut Federhorfer - Mainz & 1986. & \\
\hline 52. & Danica Petrović - Beograd & 1986. & \\
\hline 53. & Ennio Stipčević & 1986. & \\
\hline 54. & Danilo Pokorn - Ljubljana & 1986. & \\
\hline 55. & Marija Bergamo - Ljubljana & 1988. & $\begin{array}{l}\text { Voditeljica drugog dijela } \\
\text { skupa }\end{array}$ \\
\hline 56. & Danilo Pokorn - Ljubljana & 1988. & \\
\hline 57. & Jože Sivec - Ljubljana & 1988. & \\
\hline 58. & Katarina Tomašević - Beograd & 1988. & \\
\hline
\end{tabular}




\begin{tabular}{|c|c|c|c|}
\hline 59. & Andrija Tomašek & 1988. & $\begin{array}{l}\text { Predsjednik } \\
\text { predsjedništva Saveza } \\
\text { kompozitora Jugoslavije; } \\
\text { voditelj prvog dijela } \\
\text { skupa }\end{array}$ \\
\hline 60. & Ennio Stipčević & 1988. & \\
\hline 61. & Zdenka Weber & 1988. & \\
\hline 62. & Davor Merkaš & 1988. & \\
\hline 63. & Rozina Palić & 1988. & \\
\hline 64. & Katarina Livljanić & 1988. & \\
\hline 65. & Toma Prošev & 1988. & \\
\hline 66. & Sanja Šojlevska & 1988. & \\
\hline 67. & Lovro Županović & 1988. & \\
\hline 68. & Mirna Pozlović & 1988. & \\
\hline 69. & Vjera Katalinić & 1990. & \\
\hline 70. & Ennio Stipčević & 1990. & \\
\hline 71. & Katarina Bedina - Ljubljana & 1990. & \\
\hline 72. & Danica Petrović - Beograd & 1990. & \\
\hline 73. & Rosanda Pejović - Beograd & 1990. & \\
\hline 74. & Zdenka Weber & 1990. & Voditeljica \\
\hline 75. & Lovro Županović & 1990. & \\
\hline 76. & Gjuro Jakšić - Beograd & 1990. & \\
\hline 77. & Tomaž Faganel - Ljubljana & 1990. & \\
\hline 78. & Katarina Tomaševec - Beograd & 1990. & \\
\hline 79. & Vojin Komadina & 1990. & \\
\hline 80. & Andre Mohorovičić & 1991. & Voditelj \\
\hline 81. & Mira Ilijanić & 1991. & \\
\hline 82. & Miroslav Klemm & 1991. & \\
\hline 83. & Marija Mirković & 1991. & \\
\hline 84. & Adam Pintarić & 1991. & \\
\hline 85. & Zdenko Balog & 1991. & \\
\hline 86. & Željko Trstenjak & 1991. & \\
\hline 87. & Dragutin Feletar & 1991. & \\
\hline 88. & Doris Baričević & 1991. & \\
\hline 89. & Ljerka Šimunić & 1991. & \\
\hline 90. & Ljerka Perči & 1991. & \\
\hline 91. & Marija Bergamo - Ljubljana & 1992. & \\
\hline 92. & Ennio Stipčević & 1992. & \\
\hline 93. & Tomaž Faganel - Ljubljana & 1992. & \\
\hline
\end{tabular}


EDUARD VARGOVIĆ: Varaždinske barokne večeri - u susret 50 festivalskih godišta...

\begin{tabular}{|l|l|l|l|}
\hline 94. & Mijo Korade & 1992. & \\
\hline 95. & Katarina Bedina - Ljubljana & 1992. & \\
\hline 96. & Marija Riman & 1992. & \\
\hline 97. & Alojz Jembrih & 1992. & \\
\hline 98. & Stanislav Tuksar & 1992. & Voditelj \\
\hline 99. & Wolfgang J. Braun & 1994. & \\
\hline 100. & Ferdinand Meder & 1994. & \\
\hline 101. & Jagoda Meder & 1994. & \\
\hline 102. & dr. Christopher Kent & 1994. & \\
\hline 103. & mr. Zdravko Blažeković & 1994. & (Voditelj simpozija), \\
\hline 104. & Mladen Raukar & 1994. & (Stručni suradnik - \\
prevoditelj)
\end{tabular}


Radovi Zavoda za znanstveni rad HAZU Varaždin; br. 31, 2020, str. 251-297

\begin{tabular}{|c|c|c|c|}
\hline 128. & Dino Milinović & 1999. & \\
\hline 129. & Vladimir Bedenko & 1999. & \\
\hline 130. & Vladimir Maleković & 1999. & \\
\hline 131. & Đurđica Cvitanović & 1999. & \\
\hline 132. & Ivo Lentić & 1999. & \\
\hline 133. & Mijo Lončarić & 1999. & \\
\hline 134. & Ivan Zvonar & 1999. & \\
\hline 135. & Zvonimir Bartolić & 1999. & \\
\hline 136. & Alojz Jembrih & 1999. & \\
\hline 137. & Marijan Varjačić & 1999. & \\
\hline 138. & Marija Bergamo & 1999. & \\
\hline 139. & Lovro Županović & 1999. & \\
\hline 140. & Ennio Stipčević & 1999. & \\
\hline 141. & Iris Rožmarić & 1999. & \\
\hline 142. & Ljerka Šimunić & 1999. & \\
\hline 143. & Danuta Misiuda & 1999. & \\
\hline 144. & Vesna Šimičić & 1999. & \\
\hline 145. & Edita Usenik & 1999. & \\
\hline 146. & Blanda Matica & 1999. & \\
\hline 147. & Miroslav Klemm & 1999. & \\
\hline 148. & Tonka Palčić-Kombol & 1999. & \\
\hline 149. & Jasenka Splivalo & 1999. & \\
\hline 150. & Eduard Kušen & 1999. & \\
\hline 151. & Stanislav Tuksar & 2000. & Moderator skupa \\
\hline 152. & Ljerka Perči & 2000 & \\
\hline 153. & Alex Timerann & 2000 & \\
\hline 154. & Alessandro Boris Amisich & 2000 & \\
\hline 155. & Alemka Orlić & 2000 & \\
\hline 156. & Damir Barbarić & 2002. & \\
\hline 157. & Nadežda Čačinović & 2002. & \\
\hline 158. & Milan Galović & 2002. & \\
\hline 159. & Ivan Koprek & 2002. & \\
\hline 160. & Ozren Žunec & 2002. & \\
\hline 161. & Andrea Zlatar & 2002. & \\
\hline 162. & Žarko Paić & 2002. & \\
\hline 163. & Josip Talanga & 2002. & \\
\hline 164. & Tomislav Bracanović & 2002. & \\
\hline 165. & Zdenka Weber & 2010. & Moderator i autor \\
\hline
\end{tabular}


EDUARD VARGOVIĆ: Varaždinske barokne večeri - u susret 50 festivalskih godišta...

\begin{tabular}{|c|c|c|c|}
\hline 166. & Dada Ruža & 2010. & Moderator i autor \\
\hline 167. & Lucy Hallman Russel & 2010. & \\
\hline 168. & Davor Bobić & 2010. & \\
\hline 169. & Nataša Maričić & 2010. & \\
\hline 170. & Catherina Mackintosh & 2010. & \\
\hline 171. & Raymond Rojnik & 2010. & \\
\hline 172. & Saedet Midžić & 2010. & \\
\hline 173. & Višeslav Jaklin & 2010. & \\
\hline 174. & Ernest Fišer & 2010. & \\
\hline 175. & Ivan Čurković & 2010. & \\
\hline 176. & Lucija Konfic & 2010. & \\
\hline 177. & Eduard Vargović & 2010. & Koreferat \\
\hline 178. & Koncert u povodu 150 godina HAZU & & \\
\hline 179. & Zdenka Weber & 2013. & \\
\hline 180. & Michaela Freemanova & 2013. & \\
\hline 181. & Stanislav Tuksar & 2013. & \\
\hline 182. & Hrvoje Jugović & 2013. & \\
\hline 183. & Richard Fuller & 2013. & \\
\hline 184. & Allan Badley & 2013. & \\
\hline 185. & Darija Andzaković & 2013. & \\
\hline 186. & Dada Ruža & 2013. & \\
\hline 187. & Marie-Claire Taylor & 2013. & \\
\hline 188. & Vjera Katalinić & 2013. & \\
\hline 189. & Paul Bryan & 2013. & \\
\hline 190. & Seadeta Midžić & 2014. & \\
\hline 191. & Ernest Fišer & 2014. & \\
\hline 192. & Tamara Jurkić Sviben & 2014. & \\
\hline 193. & Hrvoje Jugović & 2014. & \\
\hline 194. & Marijan Kraš & 2014. & \\
\hline 195. & Erika Krpan & 2015. & \\
\hline 196. & Zdenka Weber & 2015. & \\
\hline 197. & Ennio Stipčević & 2015. & \\
\hline 198. & Hrvoje Jugović & 2015. & \\
\hline 199. & Seadeta Midžić & 2015. & \\
\hline 200. & Raymond Rojnik & 2015. & \\
\hline 201. & Marko Gašparović & 2015. & \\
\hline 202. & Nataša Maričić & 2015. & \\
\hline 203. & Eduard Vargović & 2015. & \\
\hline
\end{tabular}


Radovi Zavoda za znanstveni rad HAZU Varaždin; br. 31, 2020, str. 251-297

\begin{tabular}{|l|l|l|l|}
\hline 204. & Vladimir Huzjan & 2015. & Autor i moderator \\
\hline 205. & Ana Kaniški & 2015. & \\
\hline 206. & Jelena Blaži & 2015. & \\
\hline 207. & Vladimir Gotal & 2015. & \\
\hline 208. & Ernest Fišer & 2015. & Moderator \\
\hline 209. & Blaženka Divjak & 2017. & $\begin{array}{l}\text { Organizator: Rotary klub } \\
\text { Varaždin 1181. }\end{array}$ \\
\hline 210. & Ivan Đikić & 2017. & $\begin{array}{l}\text { Organizator: Rotary klub } \\
\text { Varaždin 1181. }\end{array}$ \\
\hline 211. & Ivica Puljak & 2017. & $\begin{array}{l}\text { Organizator: Rotary klub } \\
\text { Varaždin 1181. }\end{array}$ \\
\hline 212. & Saša Cvetojević & 2017. & $\begin{array}{l}\text { Organizator: Rotary klub } \\
\text { Varaždin 1181. }\end{array}$ \\
\hline 213. & Eduard Vargović & 2019. & \\
\hline 214. & Ana Kaniški & 2019. & \\
\hline 215. & Franc Križnar & 2019. & \\
\hline 216. & Raymond Rojnik & 2019. & \\
\hline 217. & Vladimir Gotal & 2019. & \\
\hline 218. & Mats Iljefors & 2019. & $\begin{array}{l}\text { Pismo znanstvenika } \\
\text { skupu i Festivalu }\end{array}$ \\
\hline 219. & Ernest Fišer & 2019. & Moderator skupa \\
\hline 220. & Vladimir Huzjan & 2019. & Moderator skupa \\
\hline Ukup. & & 220 \\
\hline & & & \\
\hline
\end{tabular}

Slijedeća tablica dopunjuje prethodnu pokazujući precizno broj sudjelovanja autora.

Tablica 3. Popis autora po broju sudjelovanja

\begin{tabular}{|l|l|l|l|}
\hline Redni broj & Prezime ime & Godina & $\begin{array}{l}\text { Napomena } \\
- \text { broj } \\
\text { sudjelovanja }\end{array}$ \\
\hline 1. & $\begin{array}{l}\text { Danica Petrović - } \\
\text { Beograd }\end{array}$ & $1978 . / 1982 . / 1986 . / 1990$. & 4 \\
\hline 2. & Franjo Bilić & 1978. & 1 \\
\hline 3. & Lovro Županović & $\begin{array}{l}1978 . / 1979 . / 1982 . / 19 \\
83 . / 1986 . / 1988 . / 1990 . / \\
1995 . / 1996 . / 1999 .\end{array}$ & 10 \\
\hline
\end{tabular}

26 Rotary klub Varaždin 1181. osnovan je 2003. godine (op. a.). 
EDUARD VARGOVIĆ: Varaždinske barokne večeri - u susret 50 festivalskih godišta...

\begin{tabular}{|c|c|c|c|}
\hline 4. & Gorana Doliner & 1978. & 1 \\
\hline 5. & Stanislav Tuksar & $\begin{array}{l}\text { 1978./1980./ } \\
\text { 1981./1992./2000./2013. }\end{array}$ & 6 \\
\hline 6. & Erika Krpan & 1978./1979./1980./1982./2015. & 5 \\
\hline 7. & Jože Sivec - Ljubljana & 1979./1988. & 2 \\
\hline 8. & $\begin{array}{l}\text { Miloš Milošević - } \\
\text { Kotor }\end{array}$ & 1979./1982. & 2 \\
\hline 9. & $\begin{array}{l}\text { Jelica Todorčevska - } \\
\text { Skoplje }\end{array}$ & 1979. & 1 \\
\hline 10. & Srećko Lipovčan & 1979. & 1 \\
\hline 11. & Ladislav Šaban & 1979./1981. & 2 \\
\hline 12. & Andre Lengyel & 1982. & 1 \\
\hline 13. & Ennio Stipčević & $\begin{array}{l}\text { 1982./19831986./1988./1990./ } \\
\text { 1992./1995./1996./1998./ } \\
\text { 1999./2015. }\end{array}$ & 11 \\
\hline 14. & $\begin{array}{l}\text { Dimitrije Stefanović - } \\
\text { Beograd }\end{array}$ & 1980. & 1 \\
\hline 15. & $\begin{array}{l}\text { Dragoslav Ortakov - } \\
\text { Skoplje }\end{array}$ & 1980. & 1 \\
\hline 16. & $\begin{array}{l}\text { Zija Kučukalić - } \\
\text { Sarajevo }\end{array}$ & 1983. & 1 \\
\hline 17. & Koraljka Kos & 1980. & 1 \\
\hline 18. & Vjera Katalinić-Lukšić & 1980./1990./2013. & 3 \\
\hline 19. & $\begin{array}{l}\text { Manja Radulović Vulić } \\
\text { - Podgorica }\end{array}$ & 1980. & 1 \\
\hline 20. & $\begin{array}{l}\text { Danilo Pokorn } \\
\text { Ljubljana }\end{array}$ & 1983./1986./1988. & 3 \\
\hline 21. & Andrija Tomašek & 1981./1982./ 1988. & 3 \\
\hline 22. & Herbert Seifert-Beč & 1983. & 1 \\
\hline 23. & $\begin{array}{l}\text { Hranislav Đurić (Novi } \\
\text { Sad) }\end{array}$ & 1983. & 1 \\
\hline 24. & Zdravko Blažeković & 1983. & 1 \\
\hline 25. & Ružica Bonifačić & 1983. & 1 \\
\hline 26. & Enisa Hadrović & 1983. & 1 \\
\hline 27. & Marina Jaman & 1983. & 1 \\
\hline 28. & Tatjana Kovačić & 1983. & 1 \\
\hline 29. & Tatjana Lještak & 1983. & 1 \\
\hline 30. & Maja Oršić & 1983. & 1 \\
\hline
\end{tabular}




\begin{tabular}{|c|c|c|c|}
\hline 31. & Mirjana Šimundža & 1983. & 1 \\
\hline 32. & Sanja Vukasović & 1983. & 1 \\
\hline 33. & Ivan Bošković & 1983 & 1 \\
\hline 34. & Davor Merkaš & 1988. & 1 \\
\hline 35. & Mirna Pozlović & 1988. & 1 \\
\hline 36. & Toma Prošev & 1988. & 1 \\
\hline 37. & Rozina Palić & 1988. & 1 \\
\hline 38. & Sanja Šojlevska & 1988. & 1 \\
\hline 39. & Zdenka Weber & $\begin{array}{l}\text { 1981./1988./1990./1995./2010./ } \\
\text { 2013./2015. }\end{array}$ & 7 \\
\hline 40. & Rudolf Flontzinger-Beč & 1986. & 1 \\
\hline 41. & $\begin{array}{l}\text { Hellmut Federhorfer - } \\
\text { Mainz }\end{array}$ & 1986. & 1 \\
\hline 42. & Gjura Jakšić - Beograd & 1982./1990. & 2 \\
\hline 43. & $\begin{array}{l}\text { Marija Bergamo- } \\
\text { Ljubljana }\end{array}$ & 1988./1992./1999. & 3 \\
\hline 44. & $\begin{array}{l}\text { Katarina Tomašević- } \\
\text { Beograd }\end{array}$ & 1988./1990. & 2 \\
\hline 45. & $\begin{array}{l}\text { Katarina Bedina- } \\
\text { Ljubljana }\end{array}$ & 1990./1992. & 2 \\
\hline 46. & $\begin{array}{l}\text { Rosanda Pejović- } \\
\text { Beograd }\end{array}$ & 1990. & 1 \\
\hline 47. & $\begin{array}{l}\text { Tomaž Faganel- } \\
\text { Ljubljana }\end{array}$ & 1990./1992. & 2 \\
\hline 48. & Vojin Komadina & 1990. & 1 \\
\hline 49. & Andre Mohorovičić & 1991./1996./1999. & 3 \\
\hline 50. & Mira Ilijanić & 1991. & 1 \\
\hline 51. & Miroslav Klemm & 1991./1999. & 2 \\
\hline 52. & Marija Mirković & 1991. & 1 \\
\hline 53. & Adam Pintarić & 1991. & 1 \\
\hline 54. & Zdenko Balog & 1991. & 1 \\
\hline 55. & Željko Trstenjak & 1991. & 1 \\
\hline 56. & Dragutin Feletar & 1991. & 1 \\
\hline 57. & Doris Baričević & 1991. & 1 \\
\hline 58. & Ljerka Šimunić & 1991./1999. & 2 \\
\hline 59. & Ljerka Perči & 1991./2000. & 2 \\
\hline 60. & Mijo Korade & 1992. & 1 \\
\hline 61. & Marija Riman & 1992. & 1 \\
\hline 62. & Alojz Jembrih & 1992./1999. & 2 \\
\hline
\end{tabular}


EDUARD VARGOVIĆ: Varaždinske barokne večeri - u susret 50 festivalskih godišta...

\begin{tabular}{|c|c|c|c|}
\hline 63. & Wolfgang J. Braun & 1994. & 1 \\
\hline 64. & Ferdinand Meder & 1994. & 1 \\
\hline 65. & Jagoda Meder & 1994. & 1 \\
\hline 66. & Christopher Kent & 1994. & 1 \\
\hline 67. & Zdravko Blažeković & 1994. & 1 \\
\hline 68. & Mladen Raukar & 1994. & 1 \\
\hline 69. & Božena Filipan & 1994. & 1 \\
\hline 70. & Anđelko Klobučar & 1994. & 1 \\
\hline 71. & Ivan Grabar & 1995. & 1 \\
\hline 72. & Stjepan Sraka & 1995. & 1 \\
\hline 73. & Vladimir Ščedrov & 1995. & 1 \\
\hline 74. & Dada Ruža & 1995./2010./2013. & 3 \\
\hline 75. & Izak Špralja & 1996. & 1 \\
\hline 76. & Mario Penzar & 1996./1998. & 2 \\
\hline 77. & Eduard Vargović & 1998./2010./2015./2019. & 4 \\
\hline 78. & Ivan Živanović & 1998. & 1 \\
\hline 79. & Katarina Livljanić & 1988./1998. & 2 \\
\hline 80. & Sanja Madunić & 1998. & 1 \\
\hline 81. & Renata Pokupić & 1998. & 1 \\
\hline 82. & Berislav Puškarić & 1998. & 1 \\
\hline 83. & Dino Milinović & 1999. & 1 \\
\hline 84. & Vladimir Bedenko & 1999. & 1 \\
\hline 85. & Vladimir Maleković & 1999. & 1 \\
\hline 86. & Đurđica Cvitanović & 1999. & 1 \\
\hline 87. & Ivo Lentić & 1999. & 1 \\
\hline 88. & Mijo Lončarić & 1999. & 1 \\
\hline 89. & Ivan Zvonar & 1999. & 1 \\
\hline 91. & Zvonimir Bartolić & 1999. & 1 \\
\hline 91. & Marijan Varjačić & 1999. & 1 \\
\hline 92. & Iris Rožmarić & 1999. & 1 \\
\hline 93. & Danuta Misiuda & 1999. & 1 \\
\hline 94. & Vesna Šimičić & 1999. & 1 \\
\hline 95. & Edita Usenik & 1999. & 1 \\
\hline 96. & Blanda Matica & 1999. & 1 \\
\hline 97. & Tonka Palčić-Kombol & 1999. & 1 \\
\hline 98. & Jasenka Splivalo & 1999. & 1 \\
\hline 99. & Eduard Kušen & 1999. & 1 \\
\hline 100. & Alex Timerann & 2000. & 1 \\
\hline
\end{tabular}




\begin{tabular}{|c|c|c|c|}
\hline 101. & $\begin{array}{l}\text { Alessandro Boris } \\
\text { Amisich }\end{array}$ & 2000. & 1 \\
\hline 102. & Alemka Orlić & 2000. & 1 \\
\hline 103. & Damir Barbarić & 2002. & 1 \\
\hline 104. & Nadežda Čačinović & 2002. & 1 \\
\hline 105. & Milan Galović & 2002. & 1 \\
\hline 106. & Ivan Koprek & 2002. & 1 \\
\hline 107. & Ozren Žunec & 2002. & 1 \\
\hline 108. & Andrea Zlatar & 2002. & 1 \\
\hline 109. & Žarko Paić & 2002. & 1 \\
\hline 110. & Josip Talanga & 2002. & 1 \\
\hline 111. & Tomislav Bracanović & 2002. & 1 \\
\hline 112. & Lucy Hallman Russel & 2010. & 1 \\
\hline 113. & Davor Bobić & 2010. & 1 \\
\hline 114. & Nataša Maričić & 2010./2015. & 2 \\
\hline 115. & Catherina Mackintosh & 2010. & 1 \\
\hline 116. & Raymond Rojnik & 2010./2015./2019. & 3 \\
\hline 117. & Saedet Midžić & 2010./2014./2015. & 3 \\
\hline 118. & Višeslav Jaklin & 2010. & 1 \\
\hline 119. & Ernest Fišer & 2010./2014./2015./ 2019. & $\begin{array}{l}4 \text { moder. } \\
2019 .\end{array}$ \\
\hline 120. & Ivan Čurković & 2010. & 1 \\
\hline 121. & Lucija Konfic & 2010. & 1 \\
\hline 122. & Michaela Freemanova & 2013. & 1 \\
\hline 123. & Hrvoje Jugović & 2013./2014./2015. & 3 \\
\hline 124. & Richard Fuller & 2013. & 1 \\
\hline 125. & Allan Badley & 2013. & 1 \\
\hline 126. & Darija Andzaković & 2013. & 1 \\
\hline 127. & Marie-Claire Taylor & 2013. & 1 \\
\hline 128. & Paul Bryan & 2013. & 1 \\
\hline 129. & Tamara Jurkić Sviben & 2014. & 1 \\
\hline 130. & Marijan Kraš & 2014. & 1 \\
\hline 131. & Ana Kaniški & 2015./2019. & 2 \\
\hline 132. & Vladimir Huzjan & 2015/2019. & $\begin{array}{l}2 \text { moder. } \\
2019 .\end{array}$ \\
\hline 133. & Vladimir Gotal & 2015./2019. & 2 \\
\hline 134. & Franc Križnar & 2019. & 1 \\
\hline 135. & Mats Iljefors & 2019. & 1 \\
\hline 136. & Jelena Blaži & 2015. & 1 \\
\hline
\end{tabular}


EDUARD VARGOVIĆ: Varaždinske barokne večeri - u susret 50 festivalskih godišta...

\begin{tabular}{|l|l|l|l|}
\hline 137. & Marko Gašparović & 2015. & 1 \\
\hline 138. & Blaženka Divjak & 2017. & 1 \\
\hline 139. & Ivan Đikić & 2017. & 1 \\
\hline 140. & Ivica Puljak & 2017. & 1 \\
\hline 141. & Saša Cvetojević & 2017. & 1 \\
\hline & & & $\mathbf{2 2 0}$ \\
\hline
\end{tabular}

Preglednosti radi, ove brojke možemo u tablici 4 prikazati i na drugi način, a on vrlo dojmljivo govori o velikom broju istraživača u 49 godišta postojanja Festivala i organizacije znanstvenih skupova.

Tablica 4. znanstveni skupovi - zbirni podaci

\begin{tabular}{|l|l|l|}
\hline Broj skupova & Broj autora & Broj tema (priloga) na skupovima \\
\hline 25 & 141 & 220 \\
\hline
\end{tabular}

Najviše sudjelovanja imaju:

1. Dr. sc. Ennio STIPČEVIĆ, član suradnik HAZU - 11

2. Akad. Lovro ŽUPANOVIĆ - 10

3. Dr. sc. Zdenka WEBER - 7

4. Akad. Stanislav TUKSAR - 6

Precizni podaci koje prikazujemo u nastavku govore o temama i organizaciji skupova, što će nam biti važno u razumijevanju sadržaja koji slijede.

Tablica 5. Teme i organizatori znanstvenih skupova

\begin{tabular}{|l|l|l|l|}
\hline $\begin{array}{l}\text { Redni } \\
\text { broj }\end{array}$ & Godina & Naziv skupa & Organizator \\
\hline 1. & 1978. & $\begin{array}{l}\text { Glazbena baština naroda i narodnosti } \\
\text { Jugoslavije u razdoblju od 16. do } \\
\text { 19. stoljeća te dosadašnji rezultati } \\
\text { njezina oživljavanja i uklapanja u } \\
\text { našu glazbenu baštinu. }\end{array}$ & $\begin{array}{l}\text { Muzički informativni centar } \\
\text { Koncertne direkcije Zagreb i } \\
\text { Varaždinske barokne večeri } \\
\text { (22. -23. rujna 1978.). }\end{array}$ \\
\hline 2. & 1979. & $\begin{array}{l}\text { Glazbena baština naroda i narodnosti } \\
\text { Jugoslavije u razdoblju od 16. do } \\
\text { 19. stoljeća te dosadašnji rezultati } \\
\text { njezina oživljavanja i uklapanja u } \\
\text { našu glazbenu baštinu. }\end{array}$ & $\begin{array}{l}\text { Muzički informativni centar } \\
\text { Zagreb. ( 24. - 25. rujna }\end{array}$ \\
\hline \multicolumn{2}{|l}{}
\end{tabular}




\begin{tabular}{|c|c|c|c|}
\hline 3. & 1980. & $\begin{array}{l}\text { Glazbena baština naroda i narodnosti } \\
\text { Jugoslavije u razdoblju od 16. do } 19 . \\
\text { stoljeća. }\end{array}$ & $\begin{array}{l}\text { Muzički informativni centar } \\
\text { Zagreb. (27. - 28. rujna } \\
\text { 1980.) }\end{array}$ \\
\hline 4. & 1981. & $\begin{array}{l}800 \text { godina prvog spomena grada } \\
\text { Varaždina 1181. - } 1981 .\end{array}$ & $\begin{array}{l}\text { JAZU i Skupština općine } \\
\text { Varaždin, Odbor za } \\
\text { obilježavanje } 800 \text {. godišnjice } \\
\text { grada, 1181. - } 1981 .\end{array}$ \\
\hline 5. & 1982. & $\begin{array}{l}\text { Glazbena baština naroda i narodnosti } \\
\text { Jugoslavije u razdoblju od 16. do } \\
\text { 19. stoljeća te dosadašnji rezultati } \\
\text { njezina oživljavanja i uklapanja u } \\
\text { našu glazbenu praksu. }\end{array}$ & $\begin{array}{l}\text { Muzički informativni centar } \\
\text { Zagreb. (27. - 28. rujna } \\
\text { 1982.). }\end{array}$ \\
\hline 6. & 1983. & $\begin{array}{l}\text { Glazbena baština naroda i narodnosti } \\
\text { Jugoslavije u razdoblju od 16. do } \\
\text { 19. stoljeća te dosadašnji rezultati } \\
\text { njezina oživljavanja i uklapanja u } \\
\text { našu glazbenu praksu. }\end{array}$ & $\begin{array}{l}\text { Muzički informativni centar } \\
\text { Zagreb. }\end{array}$ \\
\hline 7. & 1986. & Vinko Jelić i njegovi suvremenici & $\begin{array}{l}\text { Zavod za znanstveni } \\
\text { rad JAZU u Varaždin i } \\
\text { Varaždinske barokne večeri } \\
\text { (9. - 10. 10.). }\end{array}$ \\
\hline 8. & 1988. & $\begin{array}{l}\text { Glazbena baština naroda i narodnosti } \\
\text { Jugoslavije - slobodne teme. }\end{array}$ & $\begin{array}{l}\text { Zavod JAZU Varaždin (26. } \\
\text { rujna - 27. rujna 1988.). }\end{array}$ \\
\hline 9. & 1990. & $\begin{array}{l}\text { Proučavanje glazbenog baroka u } \\
\text { Južnih Slavena }\end{array}$ & $\begin{array}{l}\text { Zavod JAZU Varaždin, } 29 . \\
\text { rujna } 1990 .\end{array}$ \\
\hline 10. & 1991. & $\begin{array}{l}\text { Barokno graditeljstvo i likovne } \\
\text { umjetnosti Varaždina i okolice }\end{array}$ & $\begin{array}{l}\text { Zavod HAZU Varaždin, u } \\
\text { povodu } 125 \text {. obljetnice } \\
\text { HAZU } \\
\text { 24. studenoga } 1991 .\end{array}$ \\
\hline 11. & 1992. & Glazbena baština baroka. & $\begin{array}{l}\text { Zavod HAZU Varaždin, } 27 . \\
\text { rujna } 1992 .\end{array}$ \\
\hline 12 & 1994. & O orguljama Antoniusa Roemera & \\
\hline 13. & 1995. & 25 godina $V B V$ & $\begin{array}{l}\text { Zavod HAZU Varaždin, } 7 . \\
\text { studenoga } 1995 .\end{array}$ \\
\hline 14. & 1996. & Vinko Jelić i njegovi suvremenici & $\begin{array}{l}\text { Zavod HAZU Varaždin, } 4 . \\
\text { listopada } 1996 .\end{array}$ \\
\hline 15. & 1998. & Ivanu Lukačiću u spomen & $\begin{array}{l}\text { Zavod HAZU Varaždin i } \\
\text { Festivalsko vijeće VBV. }\end{array}$ \\
\hline 16. & 1999. & $\begin{array}{l}\text { Barok u Varaždinu - jučer, danas } \\
\text { sutra }\end{array}$ & $\begin{array}{l}\text { Zavod HAZU Varaždin, } \\
\text { pokrovitelj Grad Varaždin } \\
\text { 20. - 21. rujna } 1999 .\end{array}$ \\
\hline
\end{tabular}


EDUARD VARGOVIĆ: Varaždinske barokne večeri - u susret 50 festivalskih godišta...

\begin{tabular}{|c|c|c|c|}
\hline 17. & 2000. & 200. obljetnica Ivana Padovca. & $\begin{array}{l}\text { HAZU Zagreb i Zavod HAZU } \\
\text { Varaždin, 29. rujna } 2000 .\end{array}$ \\
\hline 18. & 2002. & Promišljanje umjetnosti & $\begin{array}{l}\text { Udruga za promicanje } \\
\text { znanosti Zagreb. }\end{array}$ \\
\hline 19. & 2010. & Barokna glazba-jučer, danas, sutra & $\begin{array}{l}\text { Zavod HAZU Varaždin, } 29 . \\
\text { rujna } 2010 .\end{array}$ \\
\hline 20. & 2011. & $\begin{array}{l}\text { Hrvatski barokni ansambl, koncert u } \\
\text { povodu 150. obljetnice HAZU }\end{array}$ & $\begin{array}{l}\text { 27. 09. 2011. Fanjevačka } \\
\text { crkva u Varaždinu. }\end{array}$ \\
\hline 21. & 2013. & Ivan Krstitelj Vaňhal, život i djelo & $\begin{array}{l}\text { Zavod HAZU Varaždin i VBV, } \\
\text { 30. rujna } 2013 .\end{array}$ \\
\hline 22. & 2014. & $\begin{array}{l}\text { Akademik Jurica Murai - život i } \\
\text { djelo. Muzikološki, pedagoški i } \\
\text { reproduktivni doprinos hrvatskoj } \\
\text { glazbi. U povodu 15. obljetnice smrti. }\end{array}$ & $\begin{array}{l}\text { Zavod HAZU Varaždin i KU } \\
\text { Varaždin } \\
\text { 26. rujna } 2014 .\end{array}$ \\
\hline 23. & 2015. & $\begin{array}{l}\text { Varaždinske barokne večeri-45 } \\
\text { festivalskih godišta }\end{array}$ & $\begin{array}{l}\text { Zavod HAZU Varaždin i } \\
\text { Koncertni ured Varaždin } \\
\text { 30. rujna } 2015 .\end{array}$ \\
\hline 24. & 2017. & Obrazovanje za 21. stoljeće & FOI Varaždin. \\
\hline 25. & 2019. & $\begin{array}{l}\text { Uloga Varaždinskih baroknih večeri } \\
\text { u istraživanju, očuvanju i promociji } \\
\text { hrvatske baštine baroka u } 49 \\
\text { festivalskih godišta. }\end{array}$ & $\begin{array}{l}\text { HAZU Varaždin/ Koncertni } \\
\text { ured Varaždin. }\end{array}$ \\
\hline
\end{tabular}

\section{NAKLADNIŠTVO}

Organizacija znanstvenih skupova i rezultati prezentirani na njima čine prvi vrlo važan dio znanstvenog i istraživačkog djelovanja. Međutim, u drugi dio spada jedna, po našem mišljenju, ključna aktivnost cijelog znanstveno istraživačkog rada, a to je pisanje teksta i njegovo objavljivanje. Naime, tek objavljivanjem radova s određenog skupa, zatvoren je krug svih aktivnosti u realizaciji znanstvenoistraživačkog i nakladničkog projekta. Samo tako je znanstvenoj i kulturnoj javnosti moguće valorizirati istraživanja koja su prezentirana na određenom skupu. Nedostatak u nakladničkoj realizaciji umanjuje spoznaje koje su izlagane na skupu, dakle u užem krugu slušateljstva, i tako ostaju nepoznata široj javnosti. A zadatak je znanosti da svoje spoznaje podastre svima zainteresiranima. To je slučaj i u istraživanju glazbene baštine, štoviše to je za nju upravo bitni momenat. Glazba je doista jedna od ključnih karika kulturne povijesti svakog naroda i čini ulaznicu u povijest i kulturu čovječanstva. 
Spomenuti problemi postoje i u ovom našem slučaju. Tablica koju prikazuje na početku analize vezane za nakladničke aktivnosti to najbolje pokazuje.

Tablica broj 6. Objavljeni radovi - zbirni podaci VBV i ostali radovi ${ }^{27}$

\begin{tabular}{|l|l|l|}
\hline Broj djela (časopisi i ostalo) & Broj autora & Broj stranica \\
\hline 24 & 100 & 1398 \\
\hline
\end{tabular}

Tablica jasno pokazuje razliku između sudjelovanja na skupu i objavljenih tekstova. Od 141 autora koji su na skupovima imali ukupno 220 prezentiranih tema svega njih 100 poslalo je svoje radove koji su nakon recenzijskih postupaka i objavljeni. ${ }^{28}$

\section{Objavljeni radovi do 1983. godine}

U prvom periodu održavanja znanstvenih skupova u vrijeme Festivala, dakle 1978.-1983. tiskan je Zbornik radova pod naslovom Glazbena baština knjiga 3 /1980. ${ }^{29} \mathrm{U}$ tom Zborniku objavljeni su radovi ovih autora: Franjo Bilić, Ladislav Šaban, Stanislav Tuksar, Lovro Županović, Danica Petrović, Gorana Doliner, Jelica Todorčevska i Jože Sivec. Urednik Zbornika Srećko Lipovčanu predgovoru piše: "Činjenica, da su radovi u ovoj knjizi - uostalom, kako je to u našem nizu Zbornici bilo i do sada (...) istodobno pojavljuju i na engleskom jeziku (podv. E. V.), govori o nastojanju da rezultati istraživanja naše glazbene kulture budu pristupačni i izvan naše zemlje“. ${ }^{30}$

Upravo citirane rečenice urednika pokazuje ključnu intenciju ne samo skupa već i Festivala, a to je internacionalnost. To će se u kasnijim godina pokazati kao važna činjenica, ne samo zato jer su mnogi strani sudionici prezentirali svoje radove, već su i domaći autori često to naglašavali. ${ }^{31}$

27 Bez radova pročitanih na skupu 2019. koji je održan 25. rujna u vrijeme 49. Varaždinskih baroknih večeri (op. a.).

28 U Prilogu ovog teksta nalazi se tablica svih objavljenih radova kronološki zapisano (op. a.).

29 Naklada MIC (Muzičko informativni centar) Zagreb i Varaždinske barokne večeri. MIC je bio organizator skupova, odnosno savjetovanja (op. a.).

30 Srećko Lipovčan (1942. - 2009.).

31 O potrebi povezivanja sa susjednim zemljama piše V. Kranjčević 1995. u povodu 25. godina Festivala: "Na kraju, treba naglasiti da Varaždinske barokne večeri, iz godine u godinu, zahtijevaju opću mobilizaciju svih kreativnih potencijala ne samo varaždinske sredine, nego i čitave sjeverne Hrvatske, $s$ posebnim usmjerenjem na povezivanje sa susjednim zemljama. O takvoj potrebi svjedoči i glazbena povijest ovog dijela Europe, koja, vjerujemo, garantira i mogućnost razvoja specifičnoga kulturnog turizma, o čemu nam mogu biti uzorima Austrija i Mađarska." „Varaždinske barokne večeri - 25 festi- 
EDUARD VARGOVIĆ: Varaždinske barokne večeri - u susret 50 festivalskih godišta...

\section{Radovi objavljeni nakon 1983. godine}

Drugi period o kojem govorimo, a počinje od 1983. mnogo je bogatiji i skupovima ali i objavljenim radovima. Pratit ćemo tekstove vezane za skupove održane uz Varaždinske barokne večeri. Osim toga pokazat ćemo i djelovanje Zavoda Hrvatske akademije u Varaždinu u proučavanju glazbene baštine od 1983. do danas.

Tekstovi objavljeni u časopisu Radovi ${ }^{32}$ Zavoda HAZU u Varaždinu izlagani na skupovima za vrijeme Festivala.

Pregled objavljenih radova:

1. Radovi 3/1989. U časopisu je objavljeno 6 radova vezanih za glazbu. Dva su autora svoje radove izlagali na znanstvenom skupu 1988. To su: Marija Bergamo i Andrija Tomašek. Ostali autori su: Jože Sivec, Davor Merkaš, Rozina Palić i Mirna Polzović. ${ }^{33}$

2. Radovi 4/5 1990-1991. Objavljeno je također 6 tekstova i svi su prezentirani na skupu 1990. To su ovi autori: Danilo Pokorn, Tomaž Faganel, Katarina Livljanić, Zoran Krstulović, Katarina Bedina i Zdenka Weber.

3. Radovi 6-7/1994. Objavljen je jedan tekst o glazbi koji je pročitan na skupu 1992. Riječ je o radu Katarine Bedina. ${ }^{34}$

4. Radovi 10-11/ 1989. U ovom broju koji je posvećen 85. obljetnici života akad. Andre Mohorovičića, prvog voditelja Akademijinog Zavoda u Varaždinu, objavljeni su gotovi svi referati sa skupa 1995. kojim se obilježilo 25 godina Festivala. Riječ je o ovim autorima: Lovro Županović, Dada Ruža, Vladimir Ščedrov, Stjepan Sraka i Zdenka Weber. ${ }^{35}$ U svom radu Dosadašnji prinos Varaždinskih baroknih večeri istraživanjima hrvatske glazbene bašćine i izvođenja djela iz razdoblja glazbenog baroka, akad.

valskih godina" Varaždin, 1995., str. 10.

32 Časopis Radovi je edicija Akademijinog Zavoda u Varaždinu, a počinje izlaziti godine 1986. kada je tiskan prvi broj, a predstavljen u proljeće 1987. godine (op. a.).

33 Napomena: autori: Jože Sivec, Davor Merkaš, Rozina Palić i Mirna Polzović sudjelovali su na skupu 1988. godine, ali radovi tiskani u časopisu Radovi nisu njihovi referati sa skupa. Vidjeti: Katalog Varaždinskih baroknih večeri, 1988., i časopis Radovi broj 3/1989.

34 Treba spomenuti da Emil Čić u svojem radu Glazbeni barok u Hrvatskoj referirajući se na muzikološki skup Glazbena baština baroka održan u vrijeme Festivala 1992. spominje ime Petra A. Kinderića. Međutim, u Katalogu Varaždinskih baroknih večeri u programu skupa koji je vodio Stanislav Tuksar njegovo ime nije zapisano. Vidjeti: Emil Čıć Hrvatska glazba i glazbenici, Naklada Bošković i naklada E. Čıć, Split, 2005. str. 52, i Katalog Varaždinskih baroknih večeri za 1992. godinu.

35 Na skupu su još svoje priloge pročitali Ivan Grabar i Ennio Stipčević (op. a.). 
Lovro Županović potvrđuje vrijednosti Varaždinskih baroknih večeri kad piše: „Među glazbenim priredbama festivalskog ili slično tipa u Hrvatskoj Varaždinske barokne večeri od (svog) početka zauzimaju jedinstveno mjesto iz dva razloga. Prvi je sadržan u pridjevu "barokne“ kojim je vrlo precizno istaknuta osebujna cjelovitost tematske sadržajnosti Večeri; drugi se odnosi na ostvarivanje težnje organizatora da u tako zamišljenoj sadržajnosti svoje mjesto nađe i domaća hrvatska (glazbena) tvorba samog razdoblja. ${ }^{\text {“36 }}$

5. Radovi 21/ 2010. Godine 2010. održan je međunarodni skup u povodu 40 godina Varaždinskih baroknih večeri po naslovom: Barokna glazba: jučerdanas-sutra. Na skupu je svoje priloge prezentiralo 13 sudionika: Dada Ruža, Lucy Hallman Russell, Davor Bobić, Nataša Maričić, Catherina Mackintosh, Raymond Rojnik, Seadeta Midžić, Višeslav Jaklin, Ernest Fišer, Zdenka Weber, Ivan Čurković, Lucija Konfic, Eduard Vargović. Svi radovi objavljeni su u časopisu Radovi 21/2010. koji je tiskan prije održavanja skupa.

6. Radovi 25/2014. Godine 2013. održan je međunarodni znanstveni skup: Skladatelj Ivan Krstitelj Vaňhal (1739. - 1813.) - život i djelo, a u povodu 200. godišnjice smrti. U ediciji Radovi Zavoda HAZU u Varaždinu radove su objavili: Dada Ruža, Michaela Freemanova, Allan Badley, Zdenka Weber, Vjera Katalinić, Stanislav Tuksar i Paul Bryan.

7. Radovi 26/2015. Godine 2014. u povodu 15. obljetnice smrti u Varaždinu je u vrijeme Varaždinskih barokni večeri održan znanstveni skup pod naslovom Akademik Jurica Murai - život i djelo. Muzikološki, pedagoški i reproduktivni doprinos hrvatskoj glazbi.U Radovima 26/2015. Objavljena su četiri rada. Autori su: Marijan Kraš, Seadeta Midžić, Tamara Jurkić Sviben i Hrvoje Jugović.

8. Radovi 27/2016. Godine 2015. Održan je znanstveni skup u povodu 45. godina Festivala barokne glazbe. Skup je imao naslov: Varaždinske barokne večeri-45 festivalskih godišta. S tog skupa objavljeni su tekstovi ovih autora: Erika Krpan, Raymond Rojnik, Vladimir Gotal, Ivana Maričić, Eduard Vargović/ Vladimir Huzjan. Tekst Zdenke Weber objavljen je u Radovima 28/2017.

36 Radovi 10-11/1998. str. 233. O velikim zaslugama akad. Lovre Županovića piše i Vladimir Kranjčević u već spomenutoj monografiji uz 25 godina festivala (1995.): “Čitavu tu djelatnost (istraživanja hrvatske barokne glazbene baštine - E.V.) ne bi bilo moguće razviti i održati da nije bilo bilo istraživanja i znanstvenog rada akademika Lovre Županovića, koji je tim svojim povijesnim doprinosom vezan za Varaždinske barokne večeri od njihova osnutka do danas. Tako se i na jubilarnim, 25. po redu, Baroknim večerima, zahvaljujući njemu, izvode dvije prve i nadasve važne i osebujne suvremene prezentacije stožernih skladbi hrvatske glazbene baštine: "Varaždinska misa" nepoznatog autora iz 17. stoljeća (original se čuva u Franjevačkom samostanu u Varaždinu) i osamnaest moteta Julija Skjavetića“. „Varaždinske barokne večeri - 25 festivalskih godina“ Varaždin 1995., str. 8. 
EDUARD VARGOVIĆ: Varaždinske barokne večeri - u susret 50 festivalskih godišta...
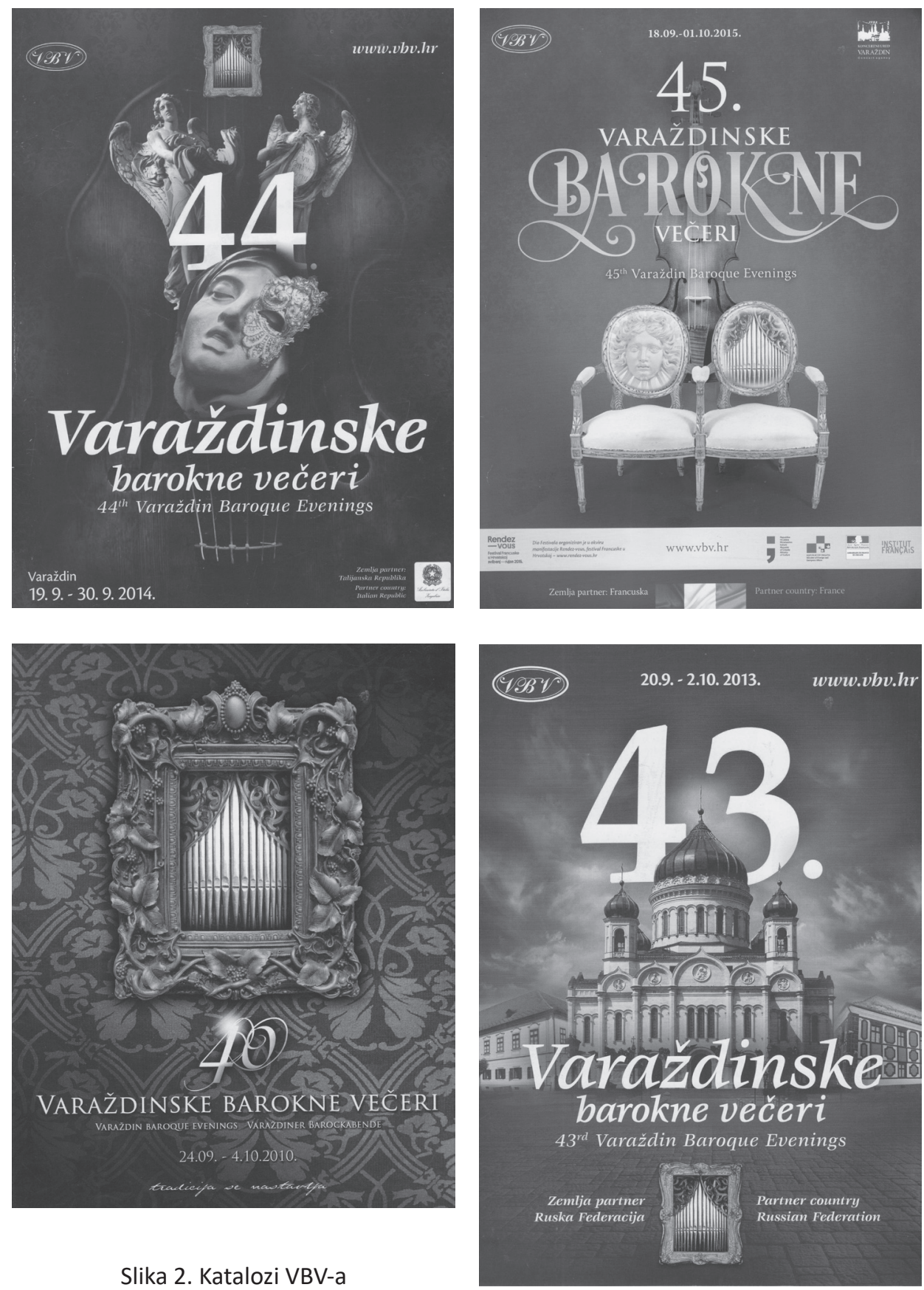

Slika 2. Katalozi VBV-a 


\section{GLAZBENA BAŠTINA, MUZIKOLOŠKE TEME, OSTALA IZDANJA ZAVODA HAZU VARAŽDIN}

U nastavku ćemo prikazati nakladničku djelatnost vezanu za sadržaje kako stoji u naslovu. Riječ je o aktivnostima Akademijinog Zavoda u Varaždinu, koje nisu realizirane za vrijeme i u suradnji s Varaždinskim baroknim večerima, osim prvog primjera koji slijedi, a tematiziraju glazbu, glazbenu baštinu, dakle muzikološke teme. Znanstvenoistraživački i nakladnički projekti i njihova realizacija pokazat će programske aktivnosti Zavoda kroz gotovo 35 godina njegova postojanja. Rezultati koje prezentiramo izgledaju ovako:

1. Prvi primjer nije rezultat djelovanja Zavoda, ali je jedan od ključnih uvjeta njegova nastanka, dakle stoji na samom njegovom početku. Zapravo, predstavljen je na isti dan i u istoj svečanosti kada je predstavljen Ugovor o osnivanju Zavoda - 24. lipnja 1983. godine. ${ }^{37}$ Riječ je o Zborniku radova sa znanstvenog skupa u povodu 800 godina prvog spomena Varaždina (1181.-1981.) održanog 1981. u Varaždinu. U toj knjizi enciklopedijskog formata tiskana su i 4 rada vezana za glazbu. ${ }^{38}$ Svoje priloge napisali su: Ladislav Šaban, Stanislav Tuksar, Andrija Tomašek i Zdenka Weber.
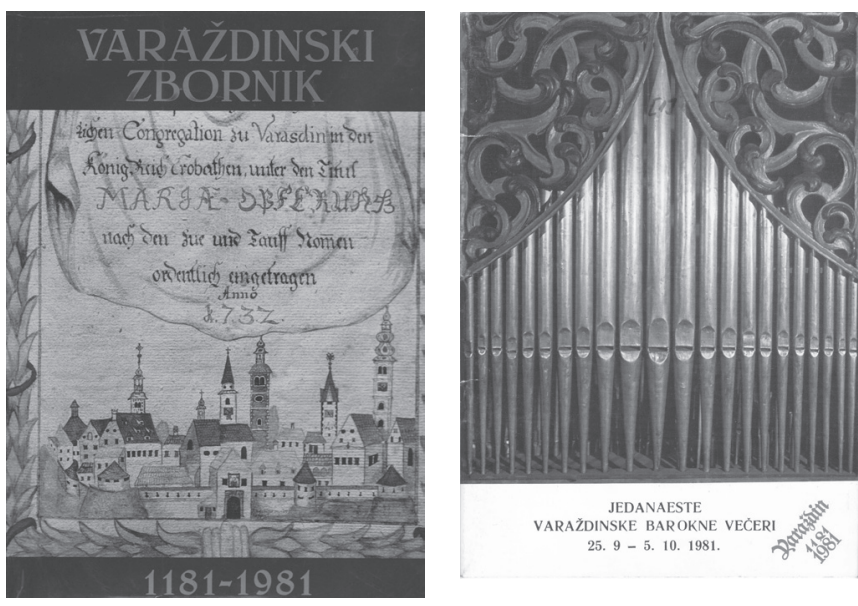

Slika 3. (L) Zbornik iz 1983. godine Slika 4. (D) Katalog VBV iz 1981. godine ${ }^{39}$

37 Svečanost predstavljanja Zbornika i potpisanog Sporazuma održana je u Vijećnici Skupštine općine Varaždin, a govorili su: akad. Andre Mohorovičić, urednik Zbornika i prvi voditelj Zavoda u Varaždinu, Ćiril Grabrovec i Petar Rihtarić (aktualni predsjednik Skupštine općine Varaždin), koji je i potpisao Sporazum o osnivanju Akademijinog Zavoda u Varaždinu (op. a.).

38 U Zborniku su objavljena 64 rada i dva uvodna izlaganja (akad. Jakova Sirotkovića, predsjednika JAZU i Ćirila Grabrovca, predsjednika Skupštine općine Varaždin). Predgovor napisao: akad. Andre Mohorovičić. Nakladnik: JAZU i Skupština općine Varaždin., 1983.

39 Vidjeti bilješku broj 9. 


\section{Zbornik 600 godina Ivanca, 1997.}

Godine 1996. u organizaciji Zavoda HAZU u Varaždinu i Grada Ivanca, a pod pokroviteljstvom Hrvatske akademije održan je dvodnevni skup: 600 godina Ivanca. Zbornik radova tiskan je i predstavljen 1997. u Ivancu. U njemu su uz ostale teme objavljena i dva rada koja govore o glazbi: Franjo Hrg piše: Glazbeni život Ivanca, a Stjepan Hranjec ima etnomuzikološki rad: Liepe ivanečke sele vu popievki. ${ }^{40}$

\section{Dada Ruža: Hrvatske pučke misne popijevke iz Međimurja}

Nakladnička aktivnost Zavoda HAZU u Varaždinu predstavila je godine 1998. djelo Dade Ruže prof. i dirigentice: Hrvatske pučke misne popijevke iz Međimurja. Knjiga je javnosti predstavljena u Katedrali uz neizbježni glazbeni dio upravo iz tiskanog izdanja. Ova će knjiga pomoći zborovođama kao odličan materijal za izbor i uvježbavanja svojih zborova, ali i nastupe. Time je na primjeren način sačuvano bogatstvo pučke misne popijevke iz Međimurja.

\section{Lepoglavski zbornik 1998. Lepoglava, 1999.}

Godinu dana prije, 1998. u Lepoglavi je održan znanstveni skup: Glazba u djelima pavlina. Lepoglavski zbornik 1998. Lepoglava 1999. ${ }^{41}$ objavljuje radove sudionika skupa. To su: Amin Armano, Koraljka Kos, Vjera Katalinić i Stanislav Tuksar. U uvodnom tekstu akad. Andre Mohorovičiću zapisuje: "Kao što čovjek rječju može izraziti svoje uvjerenje, a gestom poštovanje, tako i glazbom može izraziti svoj ushit, radost, bol i sreću."

\section{Zbornik radova Tržišna demokracija u Hrvatskoj-stanje i perspektive,} Varaždin 2000.

U Varaždinu je 2000. godine održan veliki međunarodni znanstveni skup Tržišna demokracija u Hrvatskoj - stanje i perspektive. Veliki Zbornik tiskan je do početka skupa. U njemu je tiskana i muzikološka tema koju je pripremio Ennio Stipčević pod naslovom: Starija glazba na novom tržištu (neka promišljanja, neki prijedlozi).

40 Zbornik je objavio 31 rad i uvodni tekst Adama Pintarića gradonačelnika Grada Ivanca. Nakladnik: Hrvatska akademija znanosti i umjetnosti Zavod za znanstveni rad u Varaždinu i Grad Ivanec (op. a.).

41 Lepoglavski zbornik tiskala je Turistička zajednica Lepoglave, ali je Zavod HAZU u Varaždinu obavio kompletnu pripremu, što se vidi u impresumu (op. a.). 


\section{RADOVI 12/13- 2001.}

Godine 1996. održan je u Čakovcu i Zagrebu znanstveni skup: Petar Zrinski i Fran Krsto Frankopan u povodu 325. godišnjice smrti. Glazbenu temu na tom skupu imao je akad. Lovro Županović s temom: Odjek Zrinsko-Frankopanske tragedije u glazbenoj umjetnosti. Tekst pod tim naslovom Lovro Županović pripremio je za časopis Radovi Zavoda u Varaždinu i on je tiskan u broju 12/13 za 2001. godinu.

\section{Zbornik: Stvaralački potencijali u funkciji društveno-ekonomskog i} kulturnog razvoja sjeverozapadne Hrvatske, Varaždin, 2002.

Veliki višegodišnji znanstvenoistraživački i nakladnički projekt Zavoda HAZU u Varaždinu realiziran je 2002. godine, organizacijom znanstvenog skupa i tiskanjem Zbornika radova. U odjeljku kultura u Zborniku je objavljen i rad Ennia Stipčevića: Proučavanje glazbene baštine Varaždina: skladateljski opus Ivana Wernera. Riječ je o projektu kojega će Ennio Stipčević realizirati u 2003. godini.

\section{Zbornik: $\mathbf{3 0 0}$ godina uršulinki u Varaždinu, Varaždin, 2003.}

Akademijin Zavoda u Varaždinu i Uršulinski samostan u Varaždinu, nakon višegodišnjeg rada, realizirali su međunarodni znanstvenoistraživački i nakladnički projekt u povodu 300 godina od dolaska uršulinki u Varaždinu. Organizacijom međunarodnog znanstvenog skupa i tiskanjem zbornika radova, rezultati višegodišnjih istraživanja predstavljeni su javnosti. U zborniku radova tiskani su i radovi vezani za glazbene teme, a autori su: Stanislav Tuksar, Vjera Katalinić i Ennio Stipčević.

Iste godine Ennio Stipčević je završio svoj projekt o Ivanu Werneru. Tako smo osim Zbornika radova koji je tiskan prije početka skupa, dobili i CD s kompletnim istraživačkim materijalom o Ivanu Werneru, koji je, pohranjen u Zavodu u Varaždinu i Uršulinskom samostanu. Na njemu se nalazi 258 fotografija notnog i ostalog materijala.

\section{Zbornik: Ladislav Šaban - Ostavština za budućnost, Zagreb-Varaždin 2006.}

Ovaj Zbornik radova objavio je tekstove koje su istraživači predstavili 2005. na znanstvenom susretu u povodu 20. obljetnice smrti akad. Ladislava Šabana. ${ }^{42}$ Tekstove su napisali: Erika Krpan, Koraljka Kos, Vedrana Juričić, Jakša Zlatar, Emin Armano, Nada Bezić, Marija Roščić. Knjiga ima opsežnu bibliografiju akad. Ladislava Šabana.

42 Organizatori su bili Zavod HAZU Varaždin i Varaždinske barokne večeri (op. a.). 


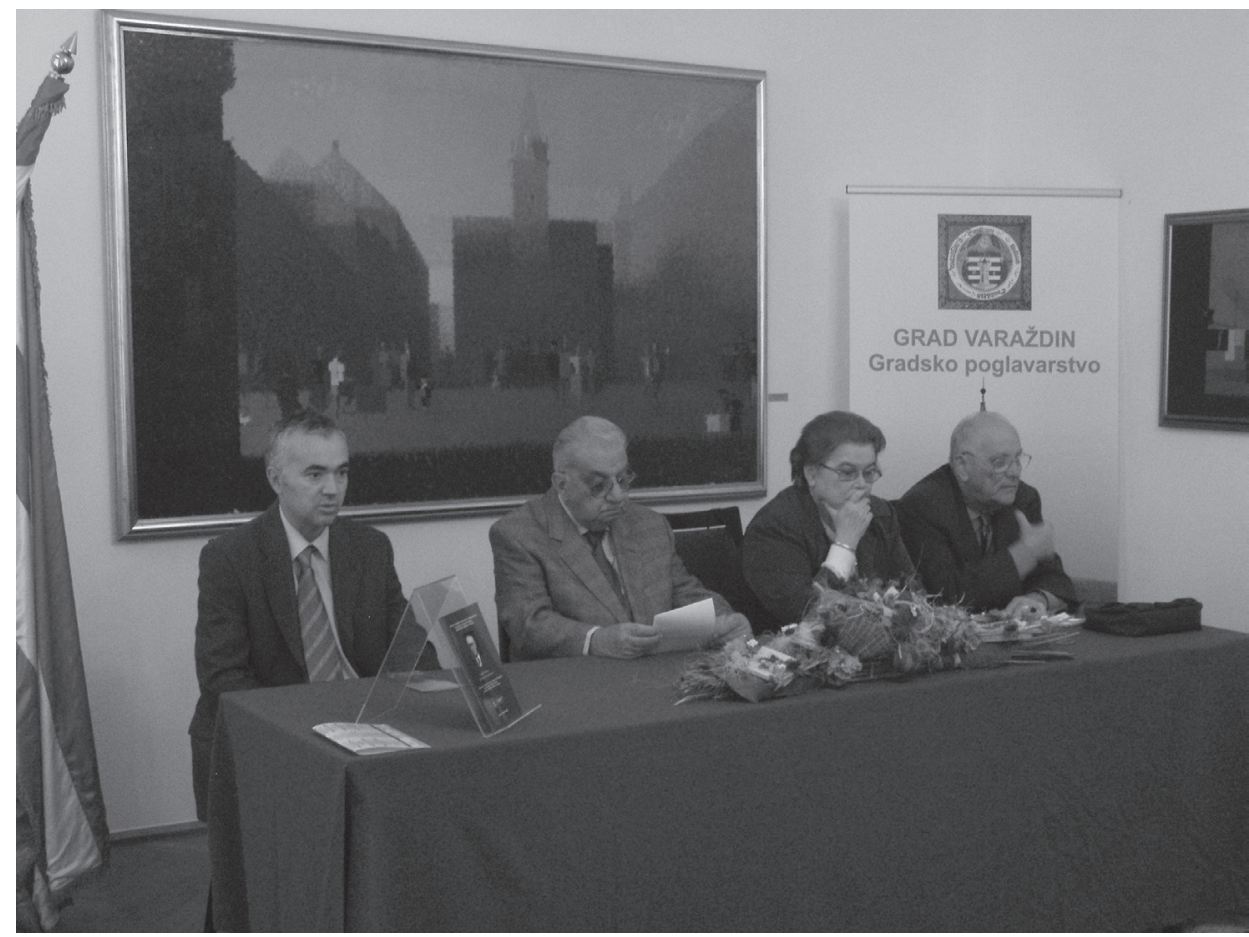

Slika 5. Predstavljanje Zbornika u Vijećnici Grada Varaždina - govorili su Ennio Stipčević, Miroslav Šicel, Erika Krpan i Vladimir Kranjčević (2006.). ${ }^{43}$

\section{RADOVI 16-17/ 2006.}

Na znanstvenom skupu u okviru manifestacije Kukuljevićevi dani 2001. u Varaždinskim Toplicama muzikologinja Dubravka Franković održala je predavanje pod naslovom: O glazbi i glazbenicima u leksikografskom radu Ivana Kukuljevića Sakcinskog. Rad je objavljen u časopisu Radovi broj 16-17 2006., koji posvećen akad. Miroslavu Šicelu u povodu 80. obljetnice života i 55. godina stvaralaštva.

\section{RADOVI 19/2008.}

Godine 2008. bila je velika obljetnica Glazbene škole Varaždin - 180 godina njezinog uspješnog djelovanja. Časopis Radovi 19/2008. objavio je 11 tekstova koji su vezani za povijest i rad naše značajne glazbene institucije. To su ovi autori: Jagoda Martinčević, Ljerka Perči, Vjera Katalinić, Klaudija Đuran, Dada Ruža, Janja Gašpar, Hrvoje Beban, Nina Jukić, Petra Pavić i Marijana Pintar (dva rada).

43 Fotografija: dokumentacija Zavod HAZU Varaždin. 


\section{RADOVI 20/2009.}

U Radovima 20/2009. muzikologinja Ivana Tomić Ferić piše opsežnu studiju: Julije Bajamonti (1744.-1800.) - između glazbene teorije i prakse.

13. ZBORNIK: 800 godina slobodnog kraljevskog grada Varaždina 1209.2009., Varaždin, 2009.

Zavod Hrvatske akademije u Varaždinu obilježio je 2009. godine veliku obljetnicu: 800 godina slobodnog kraljevskog grada Varaždina (1209.-2009.), i to višegodišnjim znanstvenoistraživačkim i nakladničkim projektom. Rezultat je prezentiran javnosti tiskanjem velikog Zbornika enciklopedijskog formata $\mathrm{i}$ dvodnevnim međunarodnim znanstvenim skupom.

$U$ sadržaju Zbornika, koji je podijeljen u tri velike cjeline: povijest, gospodarstvo i kultura tiskana su dva rada vezana za glazbu. Riječ je o prilogu autora Davora Bobića i Dragice Vitez, te muzikologinje Zdenke Weber. ${ }^{44}$

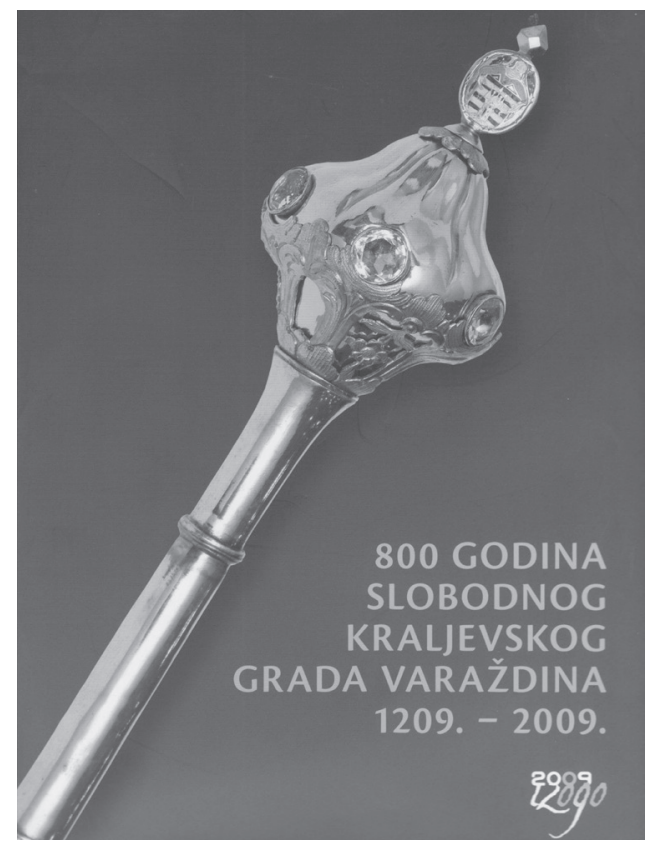

Slika 6. Zbornik 800 godina slobodnog kraljevskog grada Varaždina 1209. - 2009.

44 Zbornik radova sadrži 76 priloga te uvodne riječi akad. Miroslava Šicela, voditelja Zavoda HAZU u Varaždinu, Ivana Čehoka, gradonačelnika Grada Varaždina i Predraga Štromara, župana Varaždinske županije. Zbornik ima 933 stranice enciklopedijskog formata. Nakladnici: HAZU Zavod u Varaždinu, Grad Varaždin i Varaždinska županija. 


\section{RADOVI 24/2013.}

Ovaj broj časopisa posvećen 30. obljetnici osnutka Zavoda za znanstveni rad u Varaždin (1983.-2013.) U tom broju Ennio Stipčević piše jedan neveliki rad koji je posvećen akad. Andri Mohorovičiću, čije 100. godišnjica rođenja također obilježila u tom broju časopisa: CARLO ANTONIO NAGLI/c.1680. - 1756.) I NJEGOVA MESA CON INSTRUMENTI A 4 CONCERAT. U uvodnoj riječi autor naglašava svoj motiv posvećenosti: „Ovih nekoliko redaka posvećujem uspomeni na akademika Andriju Mohorovičića. Bio je erudit, vješt govornik, skroman i veliki čovjek. Posjedovao je rijetki dar za sintezu(...)"

\section{RADOVI 25/2014.}

U Radovima 25/2014. objavljen je rad s. Klaudije (Ane) Đuran: Uršulinka M. Pija, Stanka Lončar. Njezina glazbena uloga u uršulinskim školama i crkvi u Varaždinu.

\section{RADOVI 29/2018.}

U broju 29 za 2018. godinu časopis Radovi objavljuje dva rada vezana za glazbu. Jedan je tekst Janka Ranogajeca: Hommage Josipu Klimi 1927.-2012. 90. obljetnica rođenja, a drugi Vilene Vrbanić: Instrumenti s tipkama iz fundusa Gradskog muzeja Varaždin.

\section{ZAPIS JEDNE ZANIMLIVOSTI}

Kao što naslov sugerira - zapisujemo jednu zanimljivost. Godine 2002. Zavod HAZU i HP - Pošta Varaždin obilježili su monografijom jednu za Varaždin, ali i za Hrvatsku važnu obljetnicu: 100 godina od izgradnje prve poštanske zgrade u Hrvatskoj. U monografiji Pošta sjeverozapadne Hrvatske objavljena je Poštanska koračnica koju je skladao Davor Bobić. 


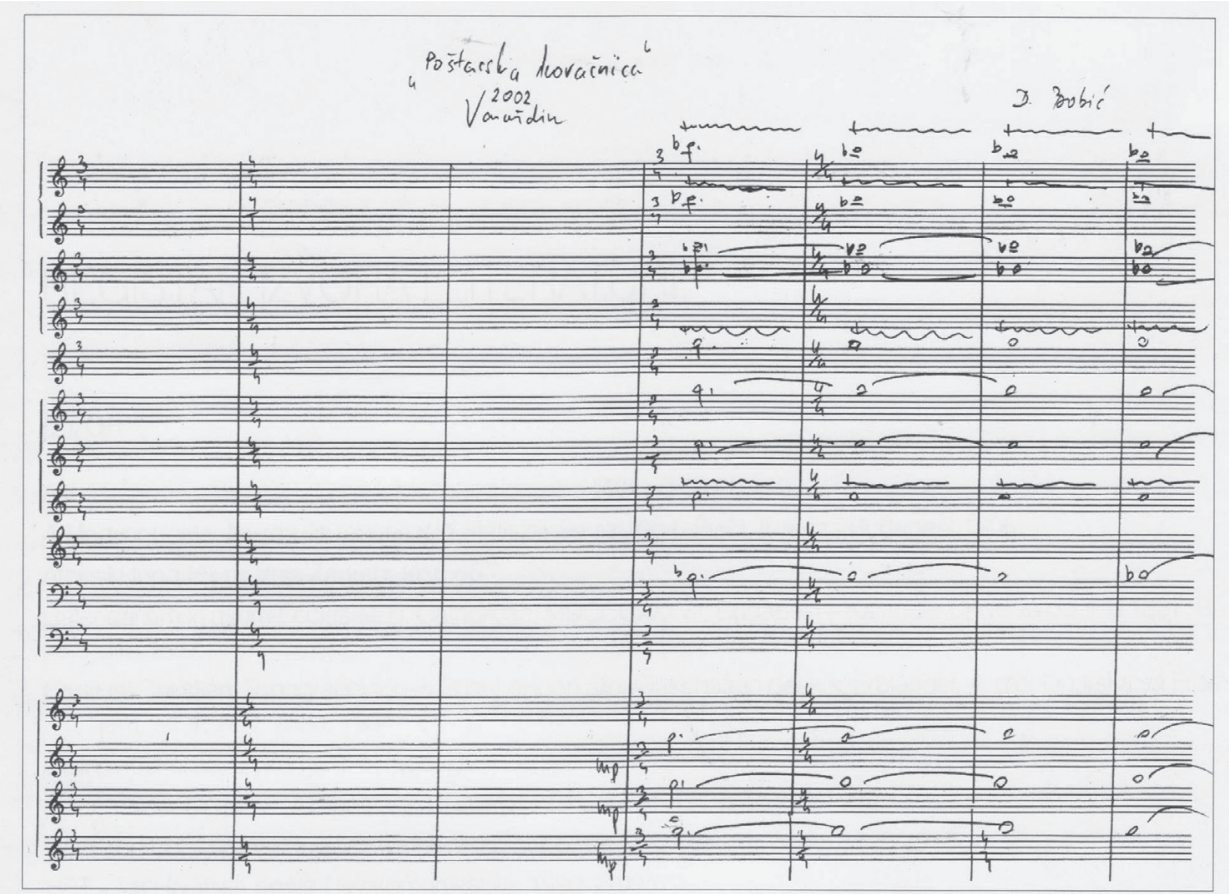

Slika 7. Fragment koračnice

\section{RAZMIŠLANJA NA KRAJU}

Razmišljanja na kraju započinjemo s dvije tablice koje nam otkrivaju i nude neke zaključke.

Tablica broj 7 prikazuje broj znanstvenih skupova. Na 25 skupova učestvovao je 140 autora koji su obradili i prezentirali ukupno 220 tema.

Tablica broj 7. Znanstveni skupovi - zbirni podaci

\begin{tabular}{|l|l|l|}
\hline Broj skupova & Broj autora & Broj tema \\
\hline 25 & 141 & 220 \\
\hline
\end{tabular}

U prosjeku na svakom skupu je govorilo više od pet sudionika. Oni su, opet u prosjeku, obradili više od osam tema. Naravno, to je tek statistika, ali ipak 
dojmljiva. Međutim, kad ovu tablicu usporedimo sa slijedećom, onda nam se odmah nudi još jedan važan zaključak. ${ }^{45}$

Tablica broj 8. Objavljeni radovi - zbirni podaci (VBV i ostali radovi)

\begin{tabular}{|l|l|l|}
\hline Broj djela (časopisi i ostalo) & Broj autora & Broj stranica \\
\hline 24 & 100 & 1398 \\
\hline
\end{tabular}

Jasno se vidi velika razlika između broja sudionika koji su učestvovali na skupovi i autora koji su poslali svoje tekstove, odnosno čiji su radovi objavljeni u nekoj od edicija.

Sve to nas navodi na ova razmišljanja:

1. Kada analiziramo, teme i autore, jasno je, i prava šteta, da dobar dio radova referiranih na skupovima nisu objavljeni. Ali to nije nedostatak samo u ovom (našem) slučaju.

2. Ipak, bogatstvo sadržaja koje smo u tekstu prezentirali, dokaz su uspješnosti Varaždinskih baroknih večeri i suradnje Festivala s uglednim institucijama - MIC/HAZU, kao i afirmiranim, ali i mladim, istraživačima, upisujući se trajno u glazbenu povijest Varaždina. Dakako, to vrijedi i za aktivnosti Akademijinog Zavoda u Varaždinu, kad je riječ o istraživanjima i čuvanju glazbene baštine i to ne samo našeg kraja.

Uz 40. obljetnicu Varaždinskih baroknih večeri, 2010. godine književnik i pjesnik Ernest Fišer piše pjesmu na kajkavskom pod naslovom: Barokne večeri (2010). Izdvojimo nekoliko stihova koji nam se nameću kao pjesnička potvrda: Festival, odnosno glazba, znak su Varaždina.

\section{(...)}

Festival baroka zdaj kinč je Varaždina, ar i vsakoga pravog domovinskog sina, most prama viečnosti, zviranjek sreče.

(...)

Idemo spati. Ali tam, gliboko vu nami zmirom čutimo mužiku srca. I nesmo sami. ${ }^{46}$

\footnotetext{
${ }_{45} \mathrm{U}$ tablicu broj 8 nisu unešeni podaci o radovima sa skupa 2019. godine budući da nisu objavljeni (op. a.).

46 Ernest FIŠER, Trošenje nade, Matica hrvatska, 2019.
} 


\section{LITERATURA}

1/ Glazbena baština, knjiga 3, MIC Zagreb i Varaždinska barokne večeri, Zagreb 1980.

2/ Emil Čıć, Hrvatska glazba i glazbenici, Naklada Bošković i Naklada E. Čić, Split 2005.

3/ Ernest FIŠER, Trošenje nade, MH, 2019.

4/ Bosiljka PERIĆ KEMPF: "Muzikološki skupovi na Varaždinski baroknim večerima". Varaždinske barokne večeri - 25 festivalskih godina, Varaždin, 1995.

5/ Vladimir KRANJČEVIĆ: "Bogatstvo barokne glazbene baštine". Varaždinske barokne večeri - 25 festivalskih godina, Varaždin, 1995.

6/ Jagoda MARTINČEVIĆ: "Dvadeset pet godišta Varaždinskih baroknih večeri", Varaždinske barokne večeri - 25 festivalskih godina, Varaždin, 1995.

7/ Dada RUŽA: Hrvatske pučke misne popijevke iz Međimurja, Zavod HAZU Varaždin Varaždin, 1998.

8/ Lepoglavski zbornik 1989., Lepoglava, 1999.

9/ Radovi 3/1989. Zavod HAZU Varaždin.

10/ Radovi 4-5/ 1990./1991. Zavod HAZU Varaždin.

11/ Radovi 6-7/ 1994. Zavod HAZU Varaždin.

12/ Radovi 10-11/ 1998. Zavod HAZU Varaždin.

13/ Radovi 12-13/ 2001. Zavod HAZU Varaždin.

14/ Radovi 16-17/ 2006. Zavod HAZU Varaždin.

15/ Radovi 19/2008. Zavod HAZU Varaždin.

16/ Radovi 20/2009. Zavod HAZU Varaždin.

17/ Radovi 21/2010. Zavod HAZU Varaždin.

18/ Radovi 24/2013. Zavod HAZU Varaždin.

19/ Radovi 25/2014. Zavod HAZU Varaždin.

20/ Radovi 26/2015. Zavod HAZU Varaždin.

21/Radovi 27/ 2016. Zavod HAZU Varaždin.

22/ Radovi 29/2018. Zavod HAZU Varaždin.

23/Varaždinski Zbornik 1181. - 1981., Varaždin, 1983.

24/Zbornik 600 godina Ivanca, Ivanec, 1997.

25/Zbornik Tržišna demokracija u Hrvatskoj-stanje i perspektive, ZagrebVaraždin, 2000.

26/ Zbornik Stvaralački potencijali u funkciji društveno-ekonomskog i kulturnog razvoja sjeverozapadne Hrvatske, Zagreb-Varaždin, 2002.

27/ Pošta sjeverozapadne Hrvatske, Hrvatska pošta i HAZU Zavod za znanstveni rad u Varaždinu, Zagreb-Varaždin 2002. 
28/ Zbornik 300 godina uršulinki u Varaždinu, Zavod HAZU Varaždin i Uršulinski samostan Varaždin, Zagreb-Varaždin, 2003.

29/ Zbornik Ladislav Šaban - ostavština za budućnost, HAZU Zavod za znanstveni rad u Varaždinu i Varaždinske barokne večeri, Zagreb-Varaždin, 2006.

30/Zbornik 800 godina slobodnog kraljevskog grada Varaždina 1209.-2019., HAZU Zavod za znanstveni rad u Varaždin, Grad Varaždin, Varaždinska županija, Zagreb- Varaždin, 2009.

31/Varaždinske barokne večeri - 25 festivalskih godišta, Nakladnik: Glazbenoscenski festival VARAŽDINSKE BAROKNE VEČERI, Varaždin, 1995.

32/ Dokumentacija: Zavod HAZU Varaždin.

33/ Ladislav ŠABAN, Glazbene mogućnosti Varaždina u 18. st. i prvoj polovici 19. stoljeća. RAD JAZU knjiga 377. - 1978.

34/ Tjednik "Varaždinske vijesti“.

35/ Eduard VARGOVIĆ / Vladimir HUZJAN: "Vrijednost i značaj popratnih programa 45 festivalskih godina Varaždinskih baroknih večeri 1971.-2015.", Radovi/27-2016. Zavod HAZU Varaždin.

36/ Zdenka WEBER: "Varaždinski festival - plod sjajne glazbene tradicije grada". U Varaždinske barokne večeri - 25 festivalskih godina, Varaždin, 1995.

37/ Lovro ŽUPANOVIĆ: "Dosadašnji prinos Varaždinskih baroknih večeri istraživanjima hrvatske glazbene bašćine i izvođenja djela iz razdoblja glazbenog baroka". Varaždinske barokne večeri - 25 festivalskih godina, Varaždin, 1995. 


\section{ZUSAMMENFASSUNG}

\section{VARAŽDINER BAROCKABENDE - DAS BEVORSTEHENDE 50-JÄHRIGE FESTIVALUUBILÄUM - WISSENSCHAFTLICHE TAGUNGEN UND TÄTIGKEIT DES INSTITUTES DER KROATISCHEN AKADEMIE DER WISSENSCHAFTEN UND KÜNSTE (HAZU) IN VARAŽDIN AN ERFORSCHUNG DES MUSIKERBES} $(1983-2019)$

Die Varaždiner Barockabende treten ihre 50-jährige erfolgreiche Tätigkeit (1971 - 2020) an. Die Arbeit thematisiert, wie es im Titel steht, die Ergebnisse der wissenschaftlichen Tagungen, aber auch die Tätigkeit des Institutes der Kroatischen Akademie der Wissenschaften und Künste in Varaždin an Erforschung des Musikerbes. Abhaltung und Realisierung der wissenschaftlichen Tagungen wird chronologisch in zwei (Haupt) Zeitabschnitte gegliedert.

1. Vom Jahr 1978 bis zum Jahr 1983, beziehungsweise bis zur Gründung des Institutes für wissenschaftliche Arbeit, damals JAZU, in Varaždin. Es wurden insgesamt 6 Tagungen abgehalten.

2. Vom Jahr 1983 bis zum Jahr 2019, in diesem Zeitabschnitt wurden 19 Tagungen abgehalten.

An 25 Tagungen haben insgesamt 141 Redner mit 220 Themen Vorträge gehalten. Die meisten Vorträge hatten: 1. Dr.sc. Ennio STIPČEVIĆ, Mitglied und Mitarbeiter bei HAZU - 11; 2. Akad. Lovro ŽUPANOVIĆ - 10; 3. Dr.sc. Zdenka WEBER - 7; 4. Akad. Stanislav TUKSAR - 6.

Wenn es um Veröffentlichung von an den Tagungen ausgestellten Arbeiten geht, so ist die Situation hier vollkommen anders. Von 141 Rednern haben 100 Autoren ihre Arbeiten zugesandt. Dies führt uns zu folgenden Schlussfolgerungen:

1. Es ist wirklich schade, dass ein Großteil der Arbeiten, die an den Tagungen abgehalten worden sind, nicht veröffentlicht wurden. Aber das ist nicht nur in diesem (unseren) Fall ein Fehler.

2. Es muss gesagt werden, dass das Reichtum an Inhalten, die wir im Text präsentiert haben, auf jeden Fall ein Nachweis des Erfolges der Varaždiner Barockabende und der Zusammenarbeit des Festivals mit den angesehenen Institutionen - MIC/HAZU, wie auch mit anekrannten, aber auch jungen Forschern ist, womit sie dauerhaft in die Musikgeschichte von Varaždin eingetragen wurden.

Schlüsselwörter: wissenschaftliche Tagungen; Kroatische Akademie der Wissenschaften und Künste; Varaždiner Barockabende; Varaždin. 


\section{PRILOG}

\section{Kronologija objavljenih tekstova:}

\section{Znanstveni skupovi - MIC i HAZU u suradnji s Varaždinskim baroknim večerima $^{47}$ \\ * ostali radovi}

\begin{tabular}{|c|c|c|c|c|}
\hline $\begin{array}{l}\text { Redni } \\
\text { broj }\end{array}$ & \begin{tabular}{|l} 
Ime i \\
prezime
\end{tabular} & Godina & Naslov rada & Knjiga \\
\hline 1. & Franjo Bilić & 1980. & $\begin{array}{l}\text { Paraliturgijska glazba } \\
\text { sjeverohrvatskog baroka- } \\
\text { spona između pučkog i } \\
\text { umjetničkog izraza }\end{array}$ & $\begin{array}{l}\text { Glazbena baština } \\
\text { Knjiga 3/ } 1980 . \\
\text { VBV }^{48}\end{array}$ \\
\hline 2. & $\begin{array}{l}\text { Ladislav } \\
\text { Šaban }\end{array}$ & 1980. & $\begin{array}{l}\text { Glazbena kultura u } \\
\text { Varaždinskoj okolici u 17. i } \\
\text { 18. stoljeću }\end{array}$ & $\begin{array}{l}\text { Glazbena baština } \\
\text { Knjiga 3/ } 1980 . \\
\text { VBV }\end{array}$ \\
\hline 3. & $\begin{array}{l}\text { Stanislav } \\
\text { Tuksar }\end{array}$ & 1980. & $\begin{array}{l}\text { Kajkavska glazbena } \\
\text { terminologija u Dictionaru } \\
\text { (1670) Jurja Habdelića }\end{array}$ & $\begin{array}{l}\text { Glazbena baština } \\
\text { Knjiga 3/ } 1980 . \\
\text { VBV }\end{array}$ \\
\hline 4. & $\begin{array}{l}\text { Lovro } \\
\text { Županović }\end{array}$ & 1980. & $\begin{array}{l}\text { Dosadašnji prinos } \\
\text { Varaždinskih baroknih } \\
\text { večeri istraživanjima } \\
\text { hrvatske glazbene baštine } \\
\text { baroknog razdoblja }\end{array}$ & $\begin{array}{l}\text { Glazbena baština } \\
\text { Knjiga 3/ } 1980 . \\
\text { VBV }\end{array}$ \\
\hline 5. & $\begin{array}{l}\text { Danica } \\
\text { Petrović }\end{array}$ & 1980. & $\begin{array}{l}\text { Srpska crkvena muzika na } \\
\text { prelazu iz XVIII u XIX vek }\end{array}$ & $\begin{array}{l}\text { Glazbena baština } \\
\text { Knjiga 3/ } 1980 . \\
\text { VBV }\end{array}$ \\
\hline 6. & $\begin{array}{l}\text { Gorana } \\
\text { Doliner }\end{array}$ & 1980. & $\begin{array}{l}\text { Specijalni obred Gospin } \\
\text { plač- prilog proučavanju } \\
\text { tradicije crkvenog pjevanja } \\
\text { u Bosni }\end{array}$ & $\begin{array}{l}\text { Glazbena baština } \\
\text { Knjiga 3/ } 1980 . \\
\text { VBV }\end{array}$ \\
\hline 7. & $\begin{array}{l}\text { Jelica } \\
\text { Todorčevska }\end{array}$ & 1980. & $\begin{array}{l}\text { Etnomuzikološki } \\
\text { rad makedonskog } \\
\text { preporoditelja Marka } \\
\text { Cepenkova (1829-1920) }\end{array}$ & $\begin{array}{l}\text { Glazbena baština } \\
\text { Knjiga 3/ } 1980 . \\
\text { VBV }\end{array}$ \\
\hline 8. & Jože Sivec & 1980. & $\begin{array}{l}\text { Ustvarjalnost renesančnega } \\
\text { skladatelja iz Maribora }\end{array}$ & $\begin{array}{l}\text { Glazbena baština } \\
\text { Knjiga 3/ } 1980 . \\
\text { VBV }\end{array}$ \\
\hline
\end{tabular}

\footnotetext{
47 Napomena: Tekstovi izlagani na skupovima zapisani su u godini objavljivanja (op. a.).

48 VBV- oznaka za tekstove izlagane na skupovima u vrijeme Varaždinskih baroknih večeri (op. a.).
} 


\begin{tabular}{|c|c|c|c|c|}
\hline 9. & $\begin{array}{l}\text { Ladislav } \\
\text { Šaban }\end{array}$ & 1981. & $\begin{array}{l}\text { Glazba u Franjevačkom } \\
\text { samostanu u Varaždinu }\end{array}$ & $\begin{array}{l}\text { Varaždinski zbornik } \\
\text { 1181.-1981. } \\
\text { Varaždin, 1983.49 } \\
\text { JAZU-SO VARAŽDIN }\end{array}$ \\
\hline 10. & $\begin{array}{l}\text { Stanislav } \\
\text { Tuksar }\end{array}$ & 1981. & $\begin{array}{l}\text { Nazivlje glazbenog } \\
\text { instrumentarija u } \\
\text { Gazofilaciju (1740.) Ivana } \\
\text { Belostenca } \\
\end{array}$ & $\begin{array}{l}\text { Varaždinski zbornik } \\
\text { 1181.-1981. } \\
\text { Varaždin, } 1983 . \\
\text { JAZU-SO VARAŽDIN }\end{array}$ \\
\hline 11. & $\begin{array}{l}\text { Andrija } \\
\text { Tomašek }\end{array}$ & 1981. & $\begin{array}{l}\text { Pjevačka društva kao faktor } \\
\text { muzičke kulture Varaždina }\end{array}$ & $\begin{array}{l}\text { Varaždinski zbornik } \\
\text { 1181.-1981. } \\
\text { Varaždin, } 1983 . \\
\text { JAZU-SO VARAŽDIN }\end{array}$ \\
\hline 12. & $\begin{array}{l}\text { Zdenka } \\
\text { Weber }\end{array}$ & 1981. & $\begin{array}{l}\text { Uloga radničke klase u } \\
\text { razvoju glazbene kulture } \\
\text { Varaždina }\end{array}$ & $\begin{array}{l}\text { Varaždinski zbornik } \\
\text { 1181.-1981. } \\
\text { Varaždin, } 1983 . \\
\text { JAZU-SO VARAŽDIN }\end{array}$ \\
\hline 13. & $\begin{array}{l}\text { Marija } \\
\text { Bergamo }\end{array}$ & 1989. & Glazba rubnih područja & $\begin{array}{l}\text { Radovi 3/ 1989.50 } \\
\text { VBV }\end{array}$ \\
\hline 14. & $\begin{array}{l}\text { Andrija } \\
\text { Tomašek }\end{array}$ & 1989. & $\begin{array}{l}\text { Slavenstvo-jedna od idejnih } \\
\text { orijentacija u djelu Franje } \\
\text { Ksavera Kuhača }\end{array}$ & $\begin{array}{l}\text { Radovi 3/ } 1989 . \\
\text { VBV }\end{array}$ \\
\hline 15. & Jože Sivec & 1989. & $\begin{array}{l}\text { Italijanska opera v Ljubljani } \\
\text { v obdoblju klasicizma }\end{array}$ & $\begin{array}{l}\text { Radovi 3/ } 1989 . \\
\text { JAZU }\end{array}$ \\
\hline 16. & $\begin{array}{l}\text { Davor } \\
\text { Merkaš }\end{array}$ & 1989. & $\begin{array}{l}\text { Odakov op. I u kontekstu } \\
\text { skladateljeva stvaralaštva } \\
\text { na području komorne } \\
\text { glazbe }\end{array}$ & $\begin{array}{l}\text { Radovi 3/ } 1989 . \\
\text { JAZU }\end{array}$ \\
\hline 17. & Rozina Palić & 1989. & $\begin{array}{l}\text { Doprinos Krste Odaka } \\
\text { duhovnoj glazbi }\end{array}$ & $\begin{array}{l}\text { Radovi 3/ } 1989 . \\
\text { JAZU }\end{array}$ \\
\hline 18. & $\begin{array}{l}\text { Mirna } \\
\text { Polzović }\end{array}$ & 1989. & $\begin{array}{l}\text { Simfonija Jadrana - Odakov } \\
\text { hommage rodnoj Dalmaciji }\end{array}$ & $\begin{array}{l}\text { Radovi 3/ } 1989 . \\
\text { JAZU }\end{array}$ \\
\hline 19. & $\begin{array}{l}\text { Danilo } \\
\text { Pokorn }\end{array}$ & 1990/1991. & $\begin{array}{l}\text { Slovenski skladatelj Jakob } \\
\text { Zupan }\end{array}$ & $\begin{array}{l}\text { Radovi } \\
4-5 / 1990 . / 1991 . \\
\text { VBV }\end{array}$ \\
\hline 20. & $\begin{array}{l}\text { Tomaž } \\
\text { Faganel }\end{array}$ & 1990/1991. & $\begin{array}{l}\text { Psalmske skladbe Janeza } \\
\text { Krstnika Dolarja }\end{array}$ & $\begin{array}{l}\text { Radovi } \\
\text { 4-5/1990./1991. } \\
\text { VBV }\end{array}$ \\
\hline
\end{tabular}

49 JAZU-HAZU - tekstovi u nakladu JAZU/HAZU.

50 Radovi Zavoda za znanstveni rad HAZU u Varaždinu. 
EDUARD VARGOVIĆ: Varaždinske barokne večeri - u susret 50 festivalskih godišta...

\begin{tabular}{|c|c|c|c|c|}
\hline 21. & $\begin{array}{l}\text { Katarina } \\
\text { Livljanić }\end{array}$ & $1990 / 1991$. & $\begin{array}{l}\text { Nepoznati rukopisni } \\
\text { procesional obrednih } \\
\text { priručnika zagrebačke } \\
\text { stolnice s kraja } 17 . \text { i prve } \\
\text { polovice } 18 \text {. stoljeća }\end{array}$ & \begin{tabular}{|l} 
Radovi \\
4-5/1990./1991. \\
VBV
\end{tabular} \\
\hline 22. & $\begin{array}{l}\text { Zoran } \\
\text { Krstulović }\end{array}$ & 1990/1991. & $\begin{array}{l}\text { Sljedovi baroka u misli } \\
\text { st. Floriana Leopolda } \\
\text { Ferdinanda Schwerdta }\end{array}$ & $\begin{array}{l}\text { Radovi } \\
4-5 / 1990 . / 1991 . \\
\text { VBV }\end{array}$ \\
\hline 23. & $\begin{array}{l}\text { Katarina } \\
\text { Bedina }\end{array}$ & 1990/1991. & $\begin{array}{l}\text { Problem glasbenega baroka } \\
\text { na slovenskem }\end{array}$ & $\begin{array}{l}\text { Radovi } \\
4-5 / 1990 . / 1991 . \\
\text { VBV }\end{array}$ \\
\hline 24. & $\begin{array}{l}\text { Zdenka } \\
\text { Weber }\end{array}$ & 1990/1991. & $\begin{array}{l}\text { Povijesno značenje } \\
\text { „Varaždinskog skladateljskog } \\
\text { kruga“ }\end{array}$ & $\begin{array}{l}\text { Radovi } \\
4-5 / 1990 . / 1991 . \\
\text { VBV }\end{array}$ \\
\hline 25. & $\begin{array}{l}\text { Katarina } \\
\text { Bedina }\end{array}$ & 1994. & $\begin{array}{l}\text { Pomen jezuitskega } \\
\text { glazbenog dela v preboju } \\
\text { baročne miselnosti na } \\
\text { slovenskem }\end{array}$ & $\begin{array}{l}\text { Radovi 6-7 } 1994 . \\
\text { VBV }\end{array}$ \\
\hline 26. & Franjo Hrg & 1996. & Glazbeni život Ivanca & $\begin{array}{l}\text { Zbornik } 600 \text { godina } \\
\text { Ivanca. } 1997 . \\
\text { HAZU }\end{array}$ \\
\hline 27. & $\begin{array}{l}\text { Stjepan } \\
\text { Hranjec }\end{array}$ & 1996. & $\begin{array}{l}\text { Liepe ivanečke sele vu } \\
\text { popievki }\end{array}$ & $\begin{array}{l}\text { Zbornik } 600 \text { godina } \\
\text { Ivanca. } 1997 . \\
\text { HAZU }\end{array}$ \\
\hline 28. & Dada Ruža & 1998. & $\begin{array}{l}\text { Hrvatske pučke misne } \\
\text { popijevke iz Međimurja }\end{array}$ & $\begin{array}{l}\text { Zavod HAZU } \\
\text { Varaždin, } 1998 . \\
\text { HAZU }\end{array}$ \\
\hline 29. & $\begin{array}{l}\text { Lovro } \\
\text { Županović }\end{array}$ & 1998. & $\begin{array}{l}\text { Dosadašnji prinos } \\
\text { Varaždinskih baroknih } \\
\text { večeri istraživanjima } \\
\text { hrvatske glazbene bašćine i } \\
\text { izvođenja djela iz razdoblja } \\
\text { glazbenog baroka }\end{array}$ & $\begin{array}{l}\text { Radovi 10/11- } \\
1998 . \\
\text { VBV }\end{array}$ \\
\hline 30. & Dada Ruža & 1998. & $\begin{array}{l}\text { Stanje povijesne izvodilačke } \\
\text { prakse u hrvatskom } \\
\text { glazbenom životu i } \\
\text { perspektive Glazbene škole } \\
\text { Varaždin na tom području. }\end{array}$ & $\begin{array}{l}\text { Radovi 10/11- } \\
1998 . \\
\text { VBV }\end{array}$ \\
\hline 31. & $\begin{array}{l}\text { Vladimir } \\
\text { Ščedrov }\end{array}$ & 1998. & $\begin{array}{l}\text { Značenje Varaždinskih } \\
\text { baroknih večeri za Glazbenu } \\
\text { školu Varaždin, njezin rad, } \\
\text { njezino mjesto u kulturnom } \\
\text { životu grada. }\end{array}$ & $\begin{array}{l}\text { Radovi 10/11- } \\
1998 . \\
\text { VBV }\end{array}$ \\
\hline
\end{tabular}




\begin{tabular}{|c|c|c|c|c|}
\hline 32. & $\begin{array}{l}\text { Stjepan } \\
\text { Sraka }\end{array}$ & 1998. & $\begin{array}{l}\text { Glazbena škola Varaždin } \\
\text { - bogata tradicija u službi } \\
\text { budućnosti. }\end{array}$ & $\begin{array}{l}\text { Radovi 10/11- } \\
1998 . \\
\text { VBV }\end{array}$ \\
\hline 33. & $\begin{array}{l}\text { Zdenka } \\
\text { Weber }\end{array}$ & 1998. & $\begin{array}{l}\text { Varaždinske barokne } \\
\text { večeri - sličnosti i razlike } \\
\text { sa svečanostima barokne } \\
\text { glazbe u Njemačkoj } \\
\text { (korespondencija s } \\
\text { Europom) }\end{array}$ & $\begin{array}{l}\text { Radovi 10/11- } \\
1998 . \\
\text { VBV }\end{array}$ \\
\hline 34. & $\begin{array}{l}\text { Emin } \\
\text { Armano }\end{array}$ & 1999. & $\begin{array}{l}\text { Orgulje pavlinskih } \\
\text { samostana u Hrvatskoj }\end{array}$ & $\begin{array}{l}\text { Lepoglavski } \\
\text { zbornik 1998., } \\
\text { Lepoglava } 1999 . \\
\text { HAZU } 51\end{array}$ \\
\hline 35. & Koraljka Kos & 1999. & $\begin{array}{l}\text { Doprinos pavlina crkvenoj } \\
\text { popijevci u Hrvatskoj }\end{array}$ & $\begin{array}{l}\text { Lepoglavski } \\
\text { zbornik 1998., } \\
\text { Lepoglava } 1999 . \\
\text { HAZU }\end{array}$ \\
\hline 36. & $\begin{array}{l}\text { Vjera } \\
\text { Katalinić }\end{array}$ & 1999. & $\begin{array}{l}\text { Skladateljska ostavština } \\
\text { Amanda Ivančića }\end{array}$ & $\begin{array}{l}\text { Lepoglavski } \\
\text { zbornik 1998., } \\
\text { Lepoglava 1999. } \\
\text { HAZU }\end{array}$ \\
\hline 37. & $\begin{array}{l}\text { Stanislav } \\
\text { Tuksar }\end{array}$ & 1999. & $\begin{array}{l}\text { Ivan Belostenec, } \\
\text { Gazophylacium- } \\
\text { terminologija vokalne } \\
\text { glazbe }\end{array}$ & $\begin{array}{l}\text { Lepoglavski } \\
\text { zbornik 1998., } \\
\text { Lepoglava } 1999 . \\
\text { HAZU }\end{array}$ \\
\hline 38. & $\begin{array}{l}\text { Ennio } \\
\text { Stipčević }\end{array}$ & 2000. & $\begin{array}{l}\text { Starija glazba na novom } \\
\text { tržištu (neka promišljanja, } \\
\text { neki prijedlozi) }\end{array}$ & $\begin{array}{l}\text { Zbornik Tržišna } \\
\text { demokracija u } \\
\text { Hrvatskoj-stanje } \\
\text { i perspektive, } \\
\text { Varaždin } 2000 . \\
\text { HAZU }\end{array}$ \\
\hline 39. & $\begin{array}{l}\text { Lovro } \\
\text { Županović }\end{array}$ & 2001. & $\begin{array}{l}\text { Odjek Zrinsko-Frankopanske } \\
\text { tragedije u glazbenoj } \\
\text { umjetnosti }\end{array}$ & $\begin{array}{l}\text { Radovi 12-13/ } \\
2001 . \\
\text { HAZU }\end{array}$ \\
\hline 40. & $\begin{array}{l}\text { Ennio } \\
\text { Stipčević }\end{array}$ & 2002. & $\begin{array}{l}\text { Proučavanje glazbene } \\
\text { baštine Varaždina: } \\
\text { skladateljski opus Ivana } \\
\text { Wernera }\end{array}$ & $\begin{array}{l}\text { Zbornik Stvaralački } \\
\text { potencijali... } \\
\text { Varaždin, } 2002 . \\
\text { HAZU }\end{array}$ \\
\hline 41. & $\begin{array}{l}\text { Stanislav } \\
\text { Tuksar }\end{array}$ & 2003. & $\begin{array}{l}\text { Rane tiskovine u glazbenoj } \\
\text { zbirci Uršulinskog } \\
\text { samostana u Varaždinu }\end{array}$ & $\begin{array}{l}\text { Zbornik } 300 \\
\text { godina uršulinki } \\
\text { u Varaždinu, } \\
\text { Varaždin, } 2003 . \\
\text { HAZU }\end{array}$ \\
\hline
\end{tabular}

51 Vidjeti bilješku broj 49. 
EDUARD VARGOVIĆ: Varaždinske barokne večeri - u susret 50 festivalskih godišta...

\begin{tabular}{|c|c|c|c|c|}
\hline 42. & $\begin{array}{l}\text { Vjera } \\
\text { Katalinić }\end{array}$ & 2003. & $\begin{array}{l}\text { Glazbeni arhiv Uršulinskog } \\
\text { samostana u Varaždinu }\end{array}$ & $\begin{array}{l}\text { Zbornik } 300 \\
\text { godina uršulinki } \\
\text { u Varaždinu, } \\
\text { Varaždin, } 2003 . \\
\text { HAZU }\end{array}$ \\
\hline 43. & $\begin{array}{l}\text { Ennio } \\
\text { Stipčević }\end{array}$ & 2003. & $\begin{array}{l}\text { Ivan Werner (1852.- } \\
\text { 1886.) i njegove skladbe } \\
\text { u samostanu uršulinki u } \\
\text { Varaždinu }\end{array}$ & $\begin{array}{l}\text { Zbornik } 300 \\
\text { godina uršulinki } \\
\text { u Varaždinu, } \\
\text { Varaždin, } 2003 . \\
\text { HAZU }\end{array}$ \\
\hline 44. & Erika Krpan & 2006. & Predgovor Zborniku & $\begin{array}{l}\text { Zbornik Ladislav } \\
\text { Šaban ostavština } \\
\text { za budućnost, } \\
\text { Varaždin, } 2006 . \\
\text { HAZU }\end{array}$ \\
\hline 45. & Koraljka Kos & 2006. & $\begin{array}{l}\text { Zov izvora-znanstvena } \\
\text { metoda Ladislava Šabana }\end{array}$ & $\begin{array}{l}\text { Zbornik Ladislav } \\
\text { Šaban ostavština } \\
\text { za budućnost, } \\
\text { Varaždin, } 2006 . \\
\text { HAZU }\end{array}$ \\
\hline 46. & $\begin{array}{l}\text { Vedrana } \\
\text { Juričić }\end{array}$ & 2006. & $\begin{array}{l}\text { Stanje ostavštine Ladislav } \\
\text { Šabana }\end{array}$ & $\begin{array}{l}\text { Zbornik Ladislav } \\
\text { Šaban ostavština } \\
\text { za budućnost, } \\
\text { Varaždin, } 2006 . \\
\text { HAZU }\end{array}$ \\
\hline 47. & $\begin{array}{l}\text { Ennio } \\
\text { Stipčević }\end{array}$ & 2006 & $\begin{array}{l}\text { Ladislav Šaban kao } \\
\text { povjesničar kulture }\end{array}$ & $\begin{array}{l}\text { Zbornik Ladislav } \\
\text { Šaban ostavština } \\
\text { za budućnost, } \\
\text { Varaždin, } 2006 . \\
\text { HAZU }\end{array}$ \\
\hline 48. & Jakša Zlatar & 2006. & $\begin{array}{l}\text { Metodičke osnove klavirske } \\
\text { pedagogije Ladislava } \\
\text { Šabana }\end{array}$ & $\begin{array}{l}\text { Zbornik Ladislav } \\
\text { Šaban ostavština } \\
\text { za budućnost, } \\
\text { Varaždin, } 2006 . \\
\text { HAZU }\end{array}$ \\
\hline 49. & $\begin{array}{l}\text { Emin } \\
\text { Armano }\end{array}$ & 2006. & $\begin{array}{l}\text { Orgulje u Hrvatskoj kao } \\
\text { tema istraživanja Ladislava } \\
\text { Šabana }\end{array}$ & $\begin{array}{l}\text { Zbornik Ladislav } \\
\text { Šaban ostavština } \\
\text { za budućnost, } \\
\text { Varaždin, } 2006 . \\
\text { HAZU }\end{array}$ \\
\hline
\end{tabular}




\begin{tabular}{|c|c|c|c|c|}
\hline 50. & Nada Bezić & 2006. & $\begin{array}{l}\text { Upornost starih } \\
\text { nesporazuma oko } \\
\text { Vatroslava Lisinskog }\end{array}$ & $\begin{array}{l}\text { Zbornik Ladislav } \\
\text { Šaban ostavština } \\
\text { za budućnost, } \\
\text { Varaždin, } 2006 . \\
\text { HAZU }\end{array}$ \\
\hline 51. & Marija Roščić & 2006. & $\begin{array}{l}\text { Ladislav Šaban - vrstan } \\
\text { portretist vremena }\end{array}$ & $\begin{array}{l}\text { Zbornik Ladislav } \\
\text { Šaban ostavština } \\
\text { za budućnost, } \\
\text { Varaždin, } 2006 . \\
\text { HAZU }\end{array}$ \\
\hline 52. & $\begin{array}{l}\text { Dubravka } \\
\text { Franković }\end{array}$ & 2006. & $\begin{array}{l}\text { O glazbi i glazbenicima u } \\
\text { leksikografskom radu Ivana } \\
\text { Kukuljevića Sakcinskog }\end{array}$ & $\begin{array}{l}\text { Radovi 16/17- } \\
2006 . \\
\text { HAZU }\end{array}$ \\
\hline 53. & $\begin{array}{l}\text { Jagoda } \\
\text { Martinčević }\end{array}$ & 2008. & $\begin{array}{l}\text { Hrvatska primadona Ruža } \\
\text { Pospiš-Baldani }\end{array}$ & $\begin{array}{l}\text { Radovi 19/2008. } \\
\text { HAZU }\end{array}$ \\
\hline 54. & Ljerka Perči & 2008. & $\begin{array}{l}\text { Prilog poznavanju } \\
\text { glazbenog života Varaždina } \\
\text { od 1927. do 1842. godine }\end{array}$ & $\begin{array}{l}\text { Radovi 19/2008. } \\
\text { HAZU }\end{array}$ \\
\hline 55. & \begin{tabular}{|l|} 
Vjera \\
Katalinić
\end{tabular} & 2008. & $\begin{array}{l}\text { Glazbena škola Varaždin - } \\
\text { poticaji i inspiracije }\end{array}$ & $\begin{array}{l}\text { Radovi 19/2008. } \\
\text { HAZU }\end{array}$ \\
\hline 56. & $\begin{array}{l}\text { Klaudija } \\
\text { Đuran }\end{array}$ & 2008. & $\begin{array}{l}\text { Glazba u Uršulinskoj pučkoj } \\
\text { i višoj djevojačkoj školi u } \\
\text { Varaždinu }\end{array}$ & $\begin{array}{l}\text { Radovi 19/2008. } \\
\text { HAZU }\end{array}$ \\
\hline 57. & Dada Ruža & 2008. & $\begin{array}{l}\text { Glazbena škola u Varaždinu } \\
\text { kao nositeljica kontinuiteta } \\
\text { glazbenog života grada } \\
\text { u posljednjem razdoblju } \\
\text { svojeg djelovanja (1936.- } \\
\text { 2008.) }\end{array}$ & $\begin{array}{l}\text { Radovi 19/2008. } \\
\text { HAZU }\end{array}$ \\
\hline 58. & Janja Gašpar & 2008. & $\begin{array}{l}\text { Razgovor s Nadom Puttar- } \\
\text { Gold }\end{array}$ & $\begin{array}{l}\text { Radovi 19/2008. } \\
\text { HAZU }\end{array}$ \\
\hline 59. & $\begin{array}{l}\text { Hrvoje } \\
\text { Beban }\end{array}$ & 2008. & $\begin{array}{l}\text { Razgovor s Višnjom } \\
\text { Mažuran }\end{array}$ & $\begin{array}{l}\text { Radovi 19/2008. } \\
\text { HAZU }\end{array}$ \\
\hline 60. & Nina Jukić & 2008. & Razgovor s Vlatkom Oršanić & $\begin{array}{l}\text { Radovi 19/2008. } \\
\text { HAZU }\end{array}$ \\
\hline 61. & Petra Pavić & 2008. & $\begin{array}{l}\text { Razgovor s Tomislavom } \\
\text { Mužekom }\end{array}$ & $\begin{array}{l}\text { Radovi 19/2008. } \\
\text { HAZU }\end{array}$ \\
\hline 62. & $\begin{array}{l}\text { Marijana } \\
\text { Pintar }\end{array}$ & 2008. & $\begin{array}{l}\text { Muzika ne poznaje granice: } \\
\text { Marijan Zuber }\end{array}$ & $\begin{array}{l}\text { Radovi 19/2008. } \\
\text { HAZU }\end{array}$ \\
\hline 63. & $\begin{array}{l}\text { Marijana } \\
\text { Pintar }\end{array}$ & 2008. & $\begin{array}{l}\text { Djelovanje Josipa Vrhovskog } \\
\text { s posebnim osvrtom na } \\
\text { varaždinsko razdoblje }\end{array}$ & $\begin{array}{l}\text { Radovi 19/2008. } \\
\text { HAZU }\end{array}$ \\
\hline
\end{tabular}


EDUARD VARGOVIĆ: Varaždinske barokne večeri - u susret 50 festivalskih godišta...

\begin{tabular}{|c|c|c|c|c|}
\hline 64. & $\begin{array}{l}\text { Ivana Tomić } \\
\text { Ferić }\end{array}$ & 2009. & $\begin{array}{l}\text { Julije Bajamonti } \\
\text { (1774.-1800.)-između } \\
\text { glazbene teorije i prakse }\end{array}$ & $\begin{array}{l}\text { Radovi 20/2009. } \\
\text { HAZU }\end{array}$ \\
\hline 65. & $\begin{array}{l}\text { Davor Bobić- } \\
\text { Dragica Vitez }\end{array}$ & 2009. & $\begin{array}{l}\text { Od slobodnog kraljevskog } \\
\text { grada do grada glazbe i } \\
\text { 39. Varaždinskih baroknih } \\
\text { večeri }\end{array}$ & $\begin{array}{l}\text { Zbornik } 800 \\
\text { godina slobodnog } \\
\text { kraljevskog grada } \\
\text { Varaždina 1209.- } \\
\text { 2009. Varaždin, } \\
2009 . \\
\text { HAZU }\end{array}$ \\
\hline 66. & $\begin{array}{l}\text { Zdenka } \\
\text { Weber }\end{array}$ & 2009. & $\begin{array}{l}\text { Glazbene svečanosti } \\
\text { hrvatske mladeži (1957.- } \\
\text { 2007.). Pola stoljeća } \\
\text { glazbenih uspjeha tisuće } \\
\text { mladih }\end{array}$ & $\begin{array}{l}\text { Zbornik } 800 \\
\text { godina slobodnog } \\
\text { kraljevskog grada } \\
\text { Varaždina 1209.- } \\
\text { 2009. Varaždin, } \\
2009 . \\
\text { HAZU }\end{array}$ \\
\hline 67. & Dada Ruža & 2010. & $\begin{array}{l}\text { Varaždinske barokne večeri } \\
\text { u zamislima i ostvarenjima }\end{array}$ & $\begin{array}{l}\text { Radovi 21/2010. } \\
\text { VBV }\end{array}$ \\
\hline 68. & $\begin{array}{l}\text { Lucy Hallman } \\
\text { Russell }\end{array}$ & 2010. & O obnovi stare glazbe & $\begin{array}{l}\text { Radovi 21/2010. } \\
\text { VBV }\end{array}$ \\
\hline 69. & Davor Bobić & 2010. & $\begin{array}{l}\text { Povijesno osviješteno } \\
\text { izvođenje barokne glazbe }\end{array}$ & $\begin{array}{l}\text { Radovi 21/2010. } \\
\text { VBV }\end{array}$ \\
\hline 70. & $\begin{array}{l}\text { Nataša } \\
\text { Maričić }\end{array}$ & 2010. & $\begin{array}{l}\text { Izvođačka praksa na } \\
\text { Varaždinskim baroknim } \\
\text { večerima }\end{array}$ & $\begin{array}{l}\text { Radovi 21/2010. } \\
\text { VBV }\end{array}$ \\
\hline 71. & $\begin{array}{l}\text { Chaterina } \\
\text { Mackintosh }\end{array}$ & 2010. & Misli i sjećanja & $\begin{array}{l}\text { Radovi 21/2010. } \\
\text { VBV }\end{array}$ \\
\hline 72. & $\begin{array}{l}\text { Rayomond } \\
\text { Rojnik }\end{array}$ & 2010. & $\begin{array}{l}\text { Diskografija } 40 \text { godina } \\
\text { Varaždinskih baroknih } \\
\text { večeri i njezin značaj za } \\
\text { promicanje i očuvanje } \\
\text { hrvatske i europske } \\
\text { glazbene baštine }\end{array}$ & $\begin{array}{l}\text { Radovi 21/2010. } \\
\text { VBV }\end{array}$ \\
\hline 73. & $\begin{array}{l}\text { Seadeta } \\
\text { Midžić }\end{array}$ & 2010. & $\begin{array}{l}\text { Varaždinske barokne večeri } \\
\text { i glazbeni program Televizije } \\
\text { Zagreb }\end{array}$ & $\begin{array}{l}\text { Radovi 21/2010. } \\
\text { VBV }\end{array}$ \\
\hline 74. & $\begin{array}{l}\text { Višeslav } \\
\text { Jaklin }\end{array}$ & 2010. & $\begin{array}{l}\text { Uloga C. Bosserta i orgulja u } \\
\text { Isusovačkoj crkvi u razvoju }\end{array}$ & $\begin{array}{l}\text { Radovi 21/2010. } \\
\text { VBV }\end{array}$ \\
\hline 75. & Ernest Fišer & 2010. & $\begin{array}{l}\text { Klub mecena Varaždinskih } \\
\text { baroknih večeri }\end{array}$ & $\begin{array}{l}\text { Radovi 21/2010. } \\
\text { VBV }\end{array}$ \\
\hline
\end{tabular}




\begin{tabular}{|c|c|c|c|c|}
\hline 76. & $\begin{array}{l}\text { Zdenka } \\
\text { Weber }\end{array}$ & 2010. & $\begin{array}{l}\text { Hrvatska glazbena } \\
\text { baština na Varaždinskim } \\
\text { baroknim večerima. } \\
\text { Ogledi o transkripcijama } \\
\text { i redakcijama: Ennio } \\
\text { Stipčević }\end{array}$ & $\begin{array}{l}\text { Radovi 21/2010. } \\
\text { VBV }\end{array}$ \\
\hline 77. & Ivan Čurković & 2010. & $\begin{array}{l}\text { Pitanje roda i izvedbene } \\
\text { prakse na primjerima opera } \\
\text { i oratorija }\end{array}$ & $\begin{array}{l}\text { Radovi 21/2010. } \\
\text { VBV }\end{array}$ \\
\hline 78. & Lucija Konić & 2010. & $\begin{array}{l}\text { Teorija i praksa u traktatu } \\
\text { "Lo spirito tartiniano" } \\
\text { Tartinijeva učenika } \\
\text { Josipa Mihovila Stratica } \\
\text { (1728.-nakon 1782.) }\end{array}$ & $\begin{array}{l}\text { Radovi 21/2010. } \\
\text { VBV }\end{array}$ \\
\hline 79. & $\begin{array}{l}\text { Eduard } \\
\text { Vargović }\end{array}$ & 2010. & $\begin{array}{l}\text { Kronologija radova iz } \\
\text { područja glazbene baštine } \\
\text { u izdanjima Zavoda za } \\
\text { znanstveni rad Hrvatske } \\
\text { akademije znanosti i } \\
\text { umjetnosti u Varaždinu } \\
\text { 1983.-2009. }\end{array}$ & $\begin{array}{l}\text { Radovi 21/2010. } \\
\text { VBV }\end{array}$ \\
\hline 80. & $\begin{array}{l}\text { Ennio } \\
\text { Stipčević }\end{array}$ & 2013. & $\begin{array}{l}\text { Carlo Antonio Nagli } \\
\text { (c.1680.-1756.) i njegova } \\
\text { mesa con instrumenti A/4 } \\
\text { concerata }\end{array}$ & $\begin{array}{l}\text { Radovi 24/ } 2013 . \\
\text { HAZU }\end{array}$ \\
\hline 81. & Dada Ruža & 2014. & $\begin{array}{l}\text { Istraživanje o Vaňhalu } \\
\text { u Hrvatskoj - poticaji, } \\
\text { smjerovi i otvorena pitanja }\end{array}$ & $\begin{array}{l}\text { Radovi 25/2014 } \\
\text { VBV }\end{array}$ \\
\hline 82. & $\begin{array}{l}\text { Michaela } \\
\text { Freemanova }\end{array}$ & 2014. & $\begin{array}{l}\text { Jan Křtitel Vaňhal and the } \\
\text { Bohemien and Moravian } \\
\text { music collection of the } \\
\text { Brothers Hospitallers } \\
\text { (Barmherzige Brüder, O.S.I.) }\end{array}$ & $\begin{array}{l}\text { Radovi 25/2014 } \\
\text { VBV }\end{array}$ \\
\hline 83. & Allan Badley & 2014. & $\begin{array}{l}\text { Chronological signifiers in } \\
\text { the concertos of Johann } \\
\text { Baptist Wanhal. }\end{array}$ & $\begin{array}{l}\text { Radovi 25/2014 } \\
\text { VBV }\end{array}$ \\
\hline 84. & $\begin{array}{l}\text { Zdenka } \\
\text { Weber }\end{array}$ & 2014. & $\begin{array}{l}\text { Beč u vrijeme Jana Křtitela } \\
\text { Vaňhala }\end{array}$ & $\begin{array}{l}\text { Radovi 25/2014 } \\
\text { VBV }\end{array}$ \\
\hline 85. & $\begin{array}{l}\text { Vjera } \\
\text { Katalinić }\end{array}$ & 2014. & $\begin{array}{l}\text { Glazbene migracije i } \\
\text { kulturni transfer: Vaňhal i } \\
\text { neki suvremenici. }\end{array}$ & $\begin{array}{l}\text { Radovi 25/2014 } \\
\text { VBV }\end{array}$ \\
\hline
\end{tabular}


EDUARD VARGOVIĆ: Varaždinske barokne večeri - u susret 50 festivalskih godišta...

\begin{tabular}{|c|c|c|c|c|}
\hline 86. & $\begin{array}{l}\text { Stanislav } \\
\text { Tuksar }\end{array}$ & 2014. & $\begin{array}{l}\text { Djela Jana Křtitela Vaňhala/ } \\
\text { Johanna Baptista Waňhala } \\
\text { u hrvatskim glazbenim } \\
\text { zbirkama }\end{array}$ & $\begin{array}{l}\text { Radovi 25/2014 } \\
\text { VBV }\end{array}$ \\
\hline 87. & Paul Bryan & 2014. & The magic of Varaždin & $\begin{array}{l}\text { Radovi 25/2014. } \\
\text { VBV }\end{array}$ \\
\hline 88. & $\begin{array}{l}\text { Klaudija } \\
\text { (Ana) Đuran }\end{array}$ & 2014. & $\begin{array}{l}\text { Uršulinka M. Pija, Stanka } \\
\text { Lončar. Njezina glazbena } \\
\text { uloga u uršulinskim školama } \\
\text { i crkvi u Varaždinu }\end{array}$ & $\begin{array}{l}\text { Radovi 25/2014. } \\
\text { Rad nije izlagan na } \\
\text { skupu posvećenom } \\
\text { J. K. Vaňhalu. } \\
\text { HAZU }\end{array}$ \\
\hline 89. & Marijan Kraš & 2015. & $\begin{array}{l}\text { Jurica Murai - Varaždin i } \\
\text { Varaždinske barokne večeri }\end{array}$ & $\begin{array}{l}\text { Radovi 26/2015. } \\
\text { VBV }\end{array}$ \\
\hline 90. & $\begin{array}{l}\text { Seadeta } \\
\text { Midžić }\end{array}$ & 2015. & $\begin{array}{l}\text { Jurica Murai u arhivu } \\
\text { Hrvatske televizije }\end{array}$ & $\begin{array}{l}\text { Radovi 26/2015. } \\
\text { VBV }\end{array}$ \\
\hline 91. & \begin{tabular}{|l|} 
Tamara \\
Jurkić Sviben
\end{tabular} & 2015. & $\begin{array}{l}\text { Pijanistički erudit Jurica } \\
\text { Murai }\end{array}$ & $\begin{array}{l}\text { Radovi 26/2015. } \\
\text { VBV }\end{array}$ \\
\hline 92. & Hrvoje Jugić & 2015. & $\begin{array}{l}\text { Sjećanja na profesora Juricu } \\
\text { Muraja. G }\end{array}$ & $\begin{array}{l}\text { Radovi 26/2015. } \\
\text { VBV }\end{array}$ \\
\hline 93. & Erika Krpan & 2016. & $\begin{array}{l}\text { Varaždinske barokne večeri } \\
\text { - poslije } 45 \text { godina }\end{array}$ & $\begin{array}{l}\text { Radovi 27/2016. } \\
\text { VBV }\end{array}$ \\
\hline 94. & $\begin{array}{l}\text { Raymond } \\
\text { Rojnik }\end{array}$ & 2016. & $\begin{array}{l}\text { Međunarodna dimenzija } \\
\text { festivala Varaždinske } \\
\text { barokne večeri }\end{array}$ & $\begin{array}{l}\text { Radovi 27/2016. } \\
\text { VBV }\end{array}$ \\
\hline 95. & $\begin{array}{l}\text { Vladimir } \\
\text { Gotal }\end{array}$ & 2016. & $\begin{array}{l}\text { Vrednovanje tonskih zapisa } \\
\text { s Varaždinskih baroknih } \\
\text { večeri i drugih koncerata } \\
\text { klasične glazbe te značenje } \\
\text { njihova očuvanja kao } \\
\text { glazbene baštine }\end{array}$ & $\begin{array}{l}\text { Radovi } 27 / 2016 . \\
\text { VBV }\end{array}$ \\
\hline 96. & $\begin{array}{l}\text { Eduard } \\
\text { Vargović/ } \\
\text { Vladimir } \\
\text { Huzjan }\end{array}$ & 2016. & $\begin{array}{l}\text { Vrijednosti i značaj } \\
\text { popratnih programa } \\
45 \text { festivalskih godišta } \\
\text { Varaždinski baroknih večeri } \\
(1971 .-2015 .)\end{array}$ & $\begin{array}{l}\text { Radovi 27/2016. } \\
\text { VBV }\end{array}$ \\
\hline 97. & Ivana Maričić & 2016. & $\begin{array}{l}\text { Varaždinski ansambli, } \\
\text { orkestri i Glazbena škola u } \\
\text { Varaždinu na Varaždinskim } \\
\text { baroknim večerima }\end{array}$ & $\begin{array}{l}\text { Radovi 27/2016. } \\
\text { VBV }\end{array}$ \\
\hline 98. & $\begin{array}{l}\text { Zdenka } \\
\text { Weber }\end{array}$ & 2017. & $\begin{array}{l}\text { Varaždinske barokne } \\
\text { večeri pod ravnateljstvom } \\
\text { hrvatskog skladatelja } \\
\text { Davora Bobića (2007.-2014.) }\end{array}$ & $\begin{array}{l}\text { Radovi 28/2017. } \\
\text { VBV }\end{array}$ \\
\hline
\end{tabular}


Radovi Zavoda za znanstveni rad HAZU Varaždin; br. 31, 2020, str. 251-297

\begin{tabular}{|l|l|l|l|l|}
\hline 99. & $\begin{array}{l}\text { Vilena } \\
\text { Vrbanić }\end{array}$ & 2018. & $\begin{array}{l}\text { Instrumenti s tipkama iz } \\
\text { fundusa Gradskog muzeja } \\
\text { Varaždin }\end{array}$ & $\begin{array}{l}\text { Radovi 29/2018. } \\
\text { HAZU }\end{array}$ \\
\hline 100. & $\begin{array}{l}\text { Janko } \\
\text { Ranogajec }\end{array}$ & 2018. & $\begin{array}{l}\text { Hommage Josipu Klimi } \\
\text { 1927.- 2012. }-90 . \\
\text { obljetnica rođenja }\end{array}$ & $\begin{array}{l}\text { Radovi 29/2018. } \\
\text { HAZU }\end{array}$ \\
\hline
\end{tabular}


